\title{
Environmental control on anaerobic oxidation of methane in the gassy sediments of Eckernförde Bay (German Baltic)
}

\author{
Tina Treude ${ }^{1}$
}

Max Planck Institute for Marine Microbiology, Department of Biogeochemistry, Celsiusstrasse 1, D-28359 Bremen, Germany

\section{Martin Krüger}

Federal Institute for Geosciences and Resources (BGR), Section Geomicrobiology, Stilleweg 2, D-30655 Hannover, Germany

\section{Antje Boetius}

Max Planck Institute for Marine Microbiology, Department of Biogeochemistry, Celsiusstrasse 1, D-28359 Bremen, Germany, and International University Bremen, Research II, Campusring 1, D-28759 Bremen, Germany

\section{Bo Barker Jorgensen}

Max Planck Institute for Marine Microbiology, Department of Biogeochemistry, Celsiusstrasse 1, D-28359 Bremen, Germany

\begin{abstract}
We investigated the effect of seasonal environmental changes on the rate and distribution of anaerobic oxidation of methane (AOM) in Eckernförde Bay sediments (German Baltic Sea) and identified organisms that are likely to be involved in the process. Surface sediments were sampled during September and March. Field rates of AOM and sulfate reduction (SR) were measured with radiotracer methods. Additional parameters were determined that potentially influence AOM, i.e., temperature, salinity, methane, sulfate, and chlorophyll $a$. Methanogenesis as well as potential rates of AOM and aerobic oxidation of methane were measured in vitro. AOM changed seasonally within the upper $20 \mathrm{~cm}$ of the sediment, with rates being between 1 and $14 \mathrm{nmol} \mathrm{cm}^{-3} \mathrm{~d}^{-1}$. Its distribution is suggested to be controlled by oxygen and sulfate penetration, temperature, as well as methane supply, leading to a shallow AOM zone during the warm productive season and to a slightly deeper AOM zone during the cold winter season. Rising methane bubbles apparently fed AOM above the sulfate-methane transition. Methanosarcinales-related anaerobic methanotrophs (ANME-2), identified with fluorescence in situ hybridization, is suggested to mediate AOM in Eckernförde Bay. These archaea are known also from other marine methane-rich locations. However, they were not directly associated with sulfate-reducing bacteria. AOM is possibly mediated solely by these archaea that show a mesophilic physiology according to the seasonal temperature changes in Eckernförde Bay.
\end{abstract}

The muddy, organic-rich sediments of Eckernförde Bay,

\footnotetext{
${ }^{1}$ Corresponding author (ttreude@ mpi-bremen.de).

Acknowledgements

We thank Captain V. Ohl, the crew of Littorina and the shipboard scientific party for excellent support during the cruises. We particularly thank W. Queisser, A. Krack, and V. Karpen for logistic help during cruise preparations as well as I. Müller, A. Rohwedder, S. Knipp, R. Appel, and A. Eppelin for technical help in the laboratory. We thank the Institut für Meereskunde, Kiel (in particular U. Rabsch) for offering laboratory facilities and the GEOMAR Research Center, Kiel, for technical support. Thanks are due to F. Abegg for providing the site map as well as additional methane data. Two anonymous reviewers are thanked for very helpful and constructive comments on the manuscript. This study was made possible by the program MUMM (Mikrobielle Umsatzraten von Methan in gashydrathaltigen Sedimenten, grant 03G0554A) supported by the Bundesministerium für Bildung und Forschung (BMBF, Germany). Further support came from the Max-Planck-Gesellschaft (MPG, Germany). This is publication GEOTECH-143 of the GEOTECHNOLOGIEN program of the BMBF and the Deutsche Forschungsgemeinschaft (DFG, Germany).
}

German Baltic Sea, have very high methane concentrations that result in gas-bubble development (Whiticar 1978; Anderson et al. 1998). The widespread occurrence of gas bubbles within the central basin leads to a characteristic acoustic turbidity in subbottom profiler records, masking the sediment reflector deeper than 1-3 m (Abegg and Anderson 1997; Wever et al. 1998). The methane is of biogenic origin produced by organic matter degradation in the Holocene deposits (Martens et al. 1999; Whiticar 2002). Methane accumulates only below sulfate penetration due to anaerobic oxidation of methane (AOM) (Albert and Martens 1995; Bussmann et al. 1999; Martens et al. 1999).

During AOM, methane is oxidized with sulfate as electron acceptor via the following net reaction:

$$
\mathrm{CH}_{4}+\mathrm{SO}_{4}^{2-} \rightarrow \mathrm{HCO}_{3}^{-}+\mathrm{HS}^{-}+\mathrm{H}_{2} \mathrm{O}
$$

In earlier studies of methane seeps, the process was found to be mediated by methanotrophic archaea, frequently associated with sulfate-reducing bacteria in a syntrophic consortium (Boetius et al. 2000; Orphan et al. 2001b; Michaelis et al. 2002). 
AOM has been demonstrated and quantified by modeling (Whiticar 1978; Martens et al. 1998; Whiticar 2002), radiotracer turnover measurements (Albert et al. 1998; Bussmann et al. 1999; Martens et al. 1999), and stable isotope analysis (Albert et al. 1998; Martens et al. 1999) in the sulfate-methane transition zone of Eckernförde Bay. AOM profiles, determined by radiotracer methods, revealed maximum rates between 10 and $44 \mathrm{nmol} \mathrm{cm}^{-3} \mathrm{~d}^{-1}$ in 23 - to 60 -cm sediment depth. However, understanding of the process at this location remains incomplete. The organisms involved in AOM have not been identified, and temporal changes have not been investigated. Eckernförde Bay exhibits a strong seasonality, e.g., of temperature, salinity, primary production, and organic-matter degradation in the sediment (Bodungen 1975; Meyer-Reil and Graf 1984; Hansen 1993). Temperature changes are reported to control the depth of the sulfatemethane transition zone in coastal sediments (Martens et al. 1986). Moreover, the location of the acoustic turbidity in Eckernförde Bay sediments, i.e., the zone of gas-bubble formation, changes seasonally, presumably caused by temperature-dependent variations in methane solubility (Wever et al. 1998). It is therefore likely that seasonal variations also influence the distribution and rate of AOM in Eckernförde Bay over the year.

Rising gas bubbles have been frequently detected in the water column of Eckernförde Bay (Jackson et al. 1998) and may also supply methane to the surface sediment. The methane ebullition is reported to be controlled by changes in sea level (Jackson et al. 1998) and thus short-term temporal changes in methane supply and methane consumption may be expected.

The present study aims for a better understanding of AOM in Eckernförde Bay sediments. Molecular, microbiological, and biogeochemical investigations were carried out to answer the following major questions:

1. Which organisms mediate AOM in Eckernförde Bay?

2. Is the rate and distribution of AOM in Eckernförde Bay controlled by seasonal changes in the environment?

3. Do rising gas bubbles transiently enhance AOM in the surface sediment?

Finally, we drew global comparisons between AOM at Eckernförde Bay and other marine sites bearing methane to discuss correlations between methane supply and methane consumption rates.

\section{Materials and methods}

Study site-Eckernförde Bay is a semienclosed bay with a maximum depth of $28 \mathrm{~m}$, located on the German Baltic Sea coast (Fig. 1) (Abegg and Anderson 1997; Wever et al. 1998). Sediment accumulation rates range between 0.3 and $1.1 \mathrm{~cm} \mathrm{yr}^{-1}$ (Nittrouer et al. 1998). The upper $2 \mathrm{~m}$ of the sediment are characterized by a high organic carbon content (4-5 wt\%) (Whiticar 2002). Bioturbation has been observed only in the top $0-1 \mathrm{~cm}$ of the sediment (Nittrouer et al. 1998).

The water column of Eckernförde Bay is strongly stratified during the summer months. As a consequence, mixing in the water column is reduced, and the thermocline

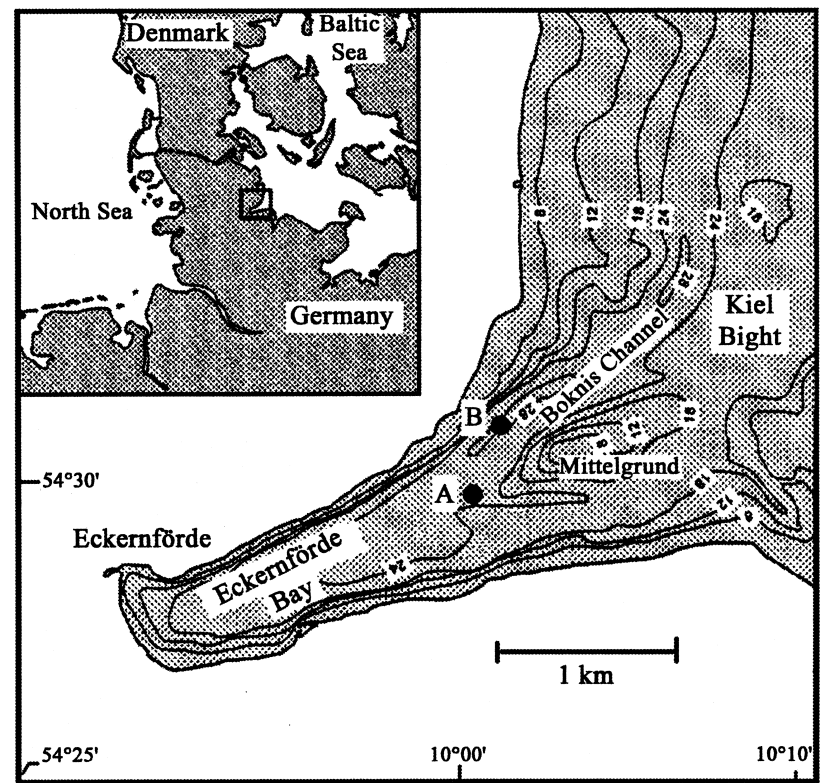

Fig. 1. Eckernförde Bay and the location of the sampling stations. Map modified from Abegg and Anderson (1997).

strengthened the formation of a deep halocline (Hansen et al. 1999). Salinities fluctuate between 14 and 24 (Milkert et al. 1995; Bussmann et al. 1999).

Primary production shows (Lenz 1996) (1) a pronounced peak in March/April dominated by diatoms, (2) moderate productivity over the summer months (June, July, and August) dominated by dinoflagellates and cyanobacteria, and (3) a moderate peak in October/November dominated by dinoflagellates and diatoms.

During late summer, when the water column is strongly stratified, oxygen saturation drops to $<10 \%$ and, occasionally, to anoxia in the bottom water (below 20-25 m) (Hansen et al. 1999). Autumn storms and a decrease in surface water temperature cause a mixing of the water column and the introduction of oxygen into deeper water layers (Meyer-Reil and Graf 1984).

Sampling sites-Samples were taken from two stations (Fig. 1). Sta. A (water depth $25 \mathrm{~m}$, position $54^{\circ} 30^{\prime} 09 \mathrm{~N}$, $10^{\circ} 00^{\prime} 57 \mathrm{E}$ ) was located west of Mittelgrund at a site formerly studied by the U.S. Naval Research Laboratory (NRL) and the Federal Armed Forces Underwater Acoustics and Marine Geophysics Research Institute (FWG) (see also Abegg and Anderson 1997; Wever et al. 1998; Martens et al. 1999). Sta. B (water depth $28 \mathrm{~m}$, position $54^{\circ} 31^{\prime} 15 \mathrm{~N}$, $10^{\circ} 01^{\prime} 28 \mathrm{E}$ ) was located in the northern Boknis channel. The stations were sampled during 1-d cruises of the German research vessel Littorina in early (5 and 6) and late (20 and 21) September 2001 as well as in early (5 and 6) March 2002.

Between the early and late September sampling, a storm occurred with a wind speed up to $80 \mathrm{~km} \mathrm{~h}^{-1}$ from the north/ northwest (M. Lehwald, pers. comm.). It was the first autumn storm after a long period of calm and warm summer weather. In March, the weather was rough, with wind from 
the south/southwest reaching $40-50 \mathrm{~km} \mathrm{~h}^{-1}$ (M. Lehwald, pers. comm.).

Measurements in the water column-Pressure, temperature, and salinity of the water column were determined by a multifunction probe (ECO-Sonde, Meerestechnik Elektronik) with an accuracy of \pm 0.01 bar for pressure, $\pm 0.01^{\circ} \mathrm{C}$ for temperature, and $\pm 0.02 \mathrm{mS} \mathrm{cm}{ }^{-1}$ for conductivity. Salinity was determined from the relation between pressure, temperature, and conductivity (Dietrich et al. 1975).

Sediment sampling-Sediment samples were taken with a small multiple corer based on the construction described by Barnett et al. (1984). This MiniMuc takes four sediment cores of up to 50-cm length, with an inner diameter of 10 $\mathrm{cm}$ within an area of $0.25 \mathrm{~m}^{2}$. The cores taken reached a length of $30-40 \mathrm{~cm}$. Unless otherwise mentioned, core subsamples were stored aboard at in situ temperature in an incubator before further investigations proceeded in the home laboratory.

Chemistry and ex situ process rates-Samples for sediment chemistry and ex situ process rate measurements, i.e., rates determined immediately after sample recovery in undisturbed sediment, were taken at Sta. A and B in early and late September as well as March. Two replicate cores of a MiniMuc deployment were subsampled with small push cores (length $30 \mathrm{~cm}$, inner diameter $26 \mathrm{~mm}$ ). A third replicate core was sampled in 1-cm intervals with cut-off syringes (see below).

Methane concentrations at time zero-On board, $2 \mathrm{~cm}^{3}$ sediment were taken at 1-cm-depth intervals with cut-off syringes immediately after recovery of the MiniMuc cores and transferred into $10-\mathrm{ml}$ glass vials filled with $5 \mathrm{ml}$ sodium hydroxide $(2.5 \% \mathrm{w} / \mathrm{w})$. The vials were closed quickly with butyl rubber stoppers, sealed with aluminum crimps, and shaken thoroughly to equilibrate the pore-water methane into the headspace. In the laboratory, the methane concentrations were determined by injection of $200 \mu \mathrm{l}$ of headspace into a gas chromatograph (5890A, Hewlett Packard) equipped with a packed stainless steel Porapak-Q column $(183 \mathrm{~m}, 0.32 \mathrm{~cm}$, 80/100 mesh, Agilent Technology) and a flame ionization detector. The carrier gas was helium at a flow rate of $30 \mathrm{ml}$ $\mathrm{min}^{-1}$. The column temperature was $40^{\circ} \mathrm{C}$.

Sulfate concentration-On board, $5 \mathrm{~cm}^{3}$ sediments were taken at $1-\mathrm{cm}$ intervals with cut-off syringes and transferred into $10-\mathrm{ml}$ plastic tubes filled with $3 \mathrm{~cm}^{3}$ zinc chloride solution $(1 \% \mathrm{w} / \mathrm{w})$. The vials were closed with plastic stoppers, shaken thoroughly, and frozen at $-25^{\circ} \mathrm{C}$. In the laboratory, the samples were thawed and centrifuged $(2,200 \times g, 10$ $\mathrm{min})$. Pore-water sulfate concentrations were measured in the supernatant using nonsuppressed ion chromatography with a Waters 510 HPLC pump, Waters WISP 712 autosampler (100- $\mu$ l injection volume), Waters IC-Pak anion exchange column $(50 \times 4.6 \mathrm{~mm})$, and a Waters 430 conductivity detector. The eluent was $1 \mathrm{mmol} \mathrm{L}^{-1}$ isophthalic acid with $10 \%$ methanol, adjusted to $\mathrm{pH} 4.5$. The flow was set to $1.0 \mathrm{ml}$ $\min ^{-1}$.
Dry weight, density, and porosity-On board, sediment samples $\left(\right.$ ca. $5 \mathrm{~cm}^{3}$ ) were taken at $1-\mathrm{cm}$ intervals with cutoff syringes and transferred into preweighed $15-\mathrm{ml}$ plastic centrifuge vials with a volume scale bar and closed with a plastic screw cap. In the laboratory, the vials were centrifuged $(2,200 \times g, 10 \mathrm{~min})$, weighed, filled with water to a defined volume, weighed again, dried, and weighed a third time. Density was calculated by dividing the sediment wet weight by the sediment volume (sediment volume with added water minus volume of added water). Porosity was calculated by dividing the pore-water volume (wet weight minus dry weight) by the sediment volume.

Anaerobic oxidation of methane (AOM) — On board, three replicate and one control push cores were taken out of two MiniMuc cores. In the laboratory, purified radioactive methane $\left({ }^{14} \mathrm{CH}_{4}\right.$ dissolved in water, injection volume $15 \mu \mathrm{l}$, activity $0.5 \mathrm{kBq}$, specific activity $2.28 \mathrm{GBq} \mathrm{mmol}^{-1}$ ) was injected into the replicate push cores at $1-\mathrm{cm}$ intervals according to the whole-core injection method of Jørgensen (1978). The push cores were incubated at in situ temperature, i.e., $10^{\circ} \mathrm{C}$ in September and $4^{\circ} \mathrm{C}$ in March, for $48 \mathrm{~h}$ in the dark. To stop bacterial activity, the sediment cores were sectioned into $1-\mathrm{cm}$ intervals and transferred into 50-ml glass vials filled with $25 \mathrm{ml}$ sodium hydroxide $(2.5 \% \mathrm{w} / \mathrm{w})$ and closed quickly with rubber stoppers. The glass vials were shaken thoroughly to equilibrate the pore-water methane between the aqueous and gaseous phases. Control push cores were first fixed before addition of tracer.

In the home laboratory, AOM was determined according to Treude et al. (2003), which is a modified method of Iversen and Blackburn (1981). In brief, a 200- $\mu$ l aliquot of the sample headspace was injected into a gas chromatograph (see previous) to measure the total methane concentration. The amount of residual ${ }^{14} \mathrm{CH}_{4}$ was determined by scintillation counting after the combustion of ${ }^{14} \mathrm{CH}_{4}$ at $850^{\circ} \mathrm{C}$ in a quartz tube filled with $\mathrm{Cu}(\mathrm{II})$-oxide and subsequent trapping of the formed ${ }^{14} \mathrm{CO}_{2}$ with phenylethylamine. The amount of microbially formed ${ }^{14} \mathrm{CO}_{2}$ was determined by scintillation counting after acidification of the aqueous sample and trapping of degassing ${ }^{14} \mathrm{CO}_{2}$ on a filter saturated with phenylethylamine. The amount of ${ }^{14} \mathrm{CO}_{2}$ recovered in samples was corrected by the amount of ${ }^{14} \mathrm{CO}_{2}$ recovered in controls. For this, a mean value of the controls was calculated and subtracted from each sample value. However, if the resulting sample value was lower than three times the standard deviation of the control mean, the sample value was considered to be zero. This correction is necessary because even sterile stock solutions of ${ }^{14} \mathrm{CH}_{4}$ dissolved in water produce an increasing ${ }^{14} \mathrm{CO}_{2}$ background over time during storage, which could influence the result.

AOM rates were calculated by two different equations as follows:

$$
\begin{aligned}
\mathrm{AOM} & =\frac{{ }^{14} \mathrm{CO}_{2} \times\left[\mathrm{CH}_{4}\right]_{t_{\text {storage }}}}{{ }^{14} \mathrm{CH}_{4_{\text {storage }}} \times t} \\
\mathrm{AOM} & =\frac{{ }^{14} \mathrm{CO}_{2} \times\left[\mathrm{CH}_{4}\right]_{t_{0}}}{\left({ }^{14} \mathrm{CO}_{2}+{ }^{14} \mathrm{CH}_{4 \text { incubation }}\right) \times t}
\end{aligned}
$$


where ${ }^{14} \mathrm{CO}_{2}$ is the radioactivity of the carbon dioxide microbially produced during incubation, $\left[\mathrm{CH}_{4}\right]_{t_{\text {storage }}}$ is the concentration of methane $\left[\mathrm{nmol} \mathrm{cm} \mathrm{cm}^{-3}\right]$ in the AOM sample after incubation and storage, $\left[\mathrm{CH}_{4}\right]_{t_{0}}$ is the concentration of methane $\left[\mathrm{nmol} \mathrm{cm} \mathrm{cm}^{-3}\right]$ at time zero, i.e., immediately after recovery of the sediment, ${ }^{14} \mathrm{CH}_{3_{\text {storage }}}$ is the radioactivity of the residual methane in the AOM sample after incubation and storage, ${ }^{14} \mathrm{CH}_{4 \text { incubation }}$ is the radioactivity of the residual methane in the AOM sample after incubation, and $t$ is the incubation time. The reason for the use of two equations for AOM calculations is a different sensitivity of the equations. Equation 2 is insensitive to physical losses of methane during sample treatment and storage, which occur in the same ratio for ${ }^{14} \mathrm{CH}_{4}$ and $\mathrm{CH}_{4}$. This is very helpful because we observed a decrease between 60 and $90 \%$ of methane after 6-10 months of sample storage. However, this equation is problematic if the total tracer turnover exceeds $10 \%$, resulting in an overestimation of the AOM rate of $\gg 10 \%$. This was the case in sediment samples of the 0 - to 5 -cm sediment section, where methane concentrations were very low and the ${ }^{14} \mathrm{CH}_{4}$ represented a large fraction of the total methane. For this depth interval, we used Eq. 3, which is insensitive to the total tracer turnover. However, because Eq. 3 is sensitive to methane losses, we recalculated the residual ${ }^{14} \mathrm{CH}_{4}$ radioactivity, i.e., after incubation but before storage, from the ratio between $\left[\mathrm{CH}_{4}\right]_{t_{\text {storage }}}$ and $\left[\mathrm{CH}_{4}\right]_{t_{0}}$ of the sample. The use of the two equations resulted, in each case, in an optimum calculation of the actual methane turnover rate.

Sulfate reduction (SR)-Sampling, injection, and incubation were the same as for AOM samples. The injected radiotracer was carrier-free ${ }^{35} \mathrm{SO}_{4}^{2-}$ (dissolved in water, injection volume $6 \mu \mathrm{l}$, activity $15 \mathrm{kBq}$, specific activity $37 \mathrm{TBq}$ $\mathrm{mmol}^{-1}$ ). To stop bacterial activity after incubation, the sediment cores were sectioned into $1-\mathrm{cm}$ intervals and transferred into $50-\mathrm{ml}$ plastic centrifuge vials filled with $20 \mathrm{ml}$ zinc acetate $(20 \% \mathrm{w} / \mathrm{w})$. Control push cores were first fixed before addition of tracer. SR rates were determined using the single step acid Cr-II method according to Fossing and Jørgensen (1989).

Chlorophyll a (Chl a) and pheophytin a (pheo a)-On board, the samples were taken with a push core. In the laboratory, the push core was sectioned into $1-\mathrm{cm}$ intervals. Two cubic centimeters of sediment of each slice was transferred into preweighed $15-\mathrm{ml}$ plastic centrifuge vials, closed with a plastic screw cap, and frozen at $-25^{\circ} \mathrm{C}$. Later, the samples were thawed and weighed. Chl $a$ and pheo a were extracted in $4 \mathrm{ml} \mathrm{90 \%} \mathrm{acetone.} \mathrm{After} \mathrm{sonication} \mathrm{(320} \mathrm{W)} \mathrm{for}$ $10 \mathrm{~min}$, the samples were centrifuged $(2,200 \times g, 5 \mathrm{~min})$ and the supernatant was transferred into $15-\mathrm{ml}$ plastic vials. The extraction was repeated twice and the supernatants of the extractions were combined. During all extractions, light was kept to a minimum to prevent a decay of the pigments. Chl $a$ was determined by fluorometry (Hitachi F-2000 fluorometer, $\lambda_{\mathrm{ex}}=428 \mathrm{~nm}, \lambda_{\mathrm{em}}=671 \mathrm{~nm}$ ). Chl $a$ (Sigma-Aldrich Chemie $\mathrm{GmbH}$ ) was used as standard. The precision of the method was $\pm 10 \%$. As labile compounds are easily degraded by acid treatment, the pigment extracts were acidified with a few drops of hydrochloric acid and measured again. The ratio of the fluorescence intensities (FI) of the acid-treated and the untreated pigment extract provides a measure of the degradability of the pigments because the resulting molecules have different fluorescence behavior than its precursor. This ratio is defined as the chlorin index (Schubert et al. 2005):

$$
\text { Chlorin Index }(\mathrm{CI})=\frac{\mathrm{FI}_{\text {acidified sample }}}{\mathrm{FI}_{\text {original sample }}}
$$

In vitro process rates - Sediment samples for in vitro rate measurements, i.e., measurements made under defined laboratory conditions, were taken at Sta. B in early September and March. On board, samples were taken by slicing MiniMuc cores into 5-cm sections. The sections were transferred into 250-ml glass bottles and sealed with butyl rubber stoppers and screw caps. Except for analysis of aerobic microbial activity, investigations in the laboratory proceeded in an $\mathrm{N}_{2} / \mathrm{CO}_{2}$ atmosphere using an anaerobic glove box (Mecaplex). Sediment samples were mixed with artificial seawater in a 1:1 ratio before further manipulations to obtain homogeneous sediment slurry. Sediment dry weights were determined after drying at $80^{\circ} \mathrm{C}$ for $2 \mathrm{~d}$. Methane concentrations were determined on a GC 14B gas chromatograph (Shimadzu) equipped with a Supel-Q Plot column (30 m $\times$ $0.53 \mathrm{~mm}$, Supelco) and a flame ionisation detector (Nauhaus et al. 2002). Sulfide was determined colorimetrically using the formation of colloidal copper sulfide (Cord-Ruwisch 1985). All in vitro rates were first determined as nmol $g$ dry $\mathrm{wt}^{-1} \mathrm{~d}^{-1}$ and recalculated into $\mathrm{nmol} \mathrm{cm} \mathrm{cm}^{-3} \mathrm{~d}^{-1}$ of the undiluted sediment using the volume: dry weight ratio of the undiluted sediment.

Potential anaerobic oxidation of methane (AOM) —With potential process rate measurements, the maximum capacity of a microbial community is determined. Potential rates are measured under optimum conditions, i.e., with no limitation in substrates. Potential AOM was determined in vitro as described by Nauhaus et al. (2002). Three cubic centimeters of sediment slurry were transferred into sterile glass tubes and mixed with $9 \mathrm{ml}$ artificial seawater medium (Widdel and Bak 1992). The tubes were sealed with butyl rubber stoppers and incubated with a headspace $(12 \mathrm{ml})$ of pure methane at atmospheric pressure $(0.1 \mathrm{MPa})$ or an $\mathrm{N}_{2} / \mathrm{CO}_{2}$ mixture (90/ $10 \mathrm{vol} / \mathrm{vol})$ in controls. In controls, all methane was removed from the slurry via repeated flushing of the headspace with $\mathrm{N}_{2} / \mathrm{CO}_{2}$ while shaking the tubes prior to incubation. All incubations were done in time series of at least five time points in triplicates at $12^{\circ} \mathrm{C}$. With slurry from $25-30 \mathrm{~cm}$ in early September, temperature-dependent potential AOM was determined at $4,8,12,16,20^{\circ} \mathrm{C}$, and $28^{\circ} \mathrm{C}$ in addition. During all incubations, the $\mathrm{pH}$ stayed constant between 7.5-7.6. Samples for chemical analyses were collected using microliter syringes (preflushed with $\mathrm{N}_{2}$ ). AOM activity was determined from the difference in sulfide production in incubations with and without methane.

AOM inhibition by oxygen-This in vitro radiotracer experiment was performed to test whether AOM activity is inhibited in the presence of oxygen. We used sediment slurry 
from the 25- to 35-cm depth interval of the early September sampling. The slurry was softly stirred for $24 \mathrm{~h}$ at $12^{\circ} \mathrm{C}$ under oxic conditions prior to incubation to ensure fully oxic conditions in the pore water. For incubations, $13 \mathrm{ml}$ of the sediment slurry were filled each into five sterile glass tubes $(16 \mathrm{ml})$ and sealed with butyl rubber stoppers. The headspace $(3 \mathrm{ml}$ ) was filled with $2 \mathrm{ml}$ air and $1 \mathrm{ml}$ methane. Five glass tubes filled with $13 \mathrm{ml}$ oxygenated artificial seawater instead of sediment slurry were used as negative controls to check for nonmicrobial activity. The headspace was the same as for the incubation of the oxygenated sediment slurry. Five glass tubes filled with $13 \mathrm{ml}$ of the original anoxic sediment slurry were used as positive controls to test AOM activity under anoxic conditions. In this case, the headspace $(3 \mathrm{ml})$ was filled with $2 \mathrm{ml} \mathrm{N} / 2 / \mathrm{CO}_{2}$ mixture $(90 / 10 \mathrm{vol} / \mathrm{vol})$ and 1 $\mathrm{ml}$ methane. Purified radioactive methane $\left({ }^{14} \mathrm{CH}_{4}\right.$ gaseous, injection volume $10 \mu \mathrm{l}$, activity $0.2 \mathrm{kBq}$, specific activity $2.28 \mathrm{GBq} \mathrm{mmol}{ }^{-1}$ ) was injected into each headspace. The glass tubes were stored horizontally and gently shaken for 5 $\mathrm{d}$ at $12^{\circ} \mathrm{C}$. After incubation, the sediment slurry/seawater medium and the headspace were transferred into $50-\mathrm{ml}$ glass vials filled with $25 \mathrm{ml}$ sodium hydroxide $(2.5 \% \mathrm{w} / \mathrm{w})$ and closed with rubber stoppers. Further analysis was the same as for ${ }^{14} \mathrm{C}$ AOM samples described above.

Coupling of AOM and $S R$ - This in vitro radiotracer experiment was performed to test whether AOM activity is impacted negatively when SR is inhibited. Molybdate was used as inhibitor for the enzymatic pathway of SR (Hansen et al. 1998). We used methane-amended $\left(0.6 \mathrm{mmol} \mathrm{L}^{-1}\right)$ sediment slurry from the $25-$ to $35-\mathrm{cm}$ depth interval of the early September sampling. Ten sterile glass tubes $(16 \mathrm{ml})$ were filled with sediment slurry and closed bubble free. Five of the glass tubes were supplemented with Na-molybdate (final concentration in the slurry: $10 \mathrm{nmol} \mathrm{L}{ }^{-1}$ ). Five additional glass tubes were filled bubble free with anoxic artificial seawater instead of sediment slurry to check for nonmicrobial activity. Purified radioactive methane $\left({ }^{14} \mathrm{CH}_{4}\right.$ dissolved in water, injection volume $50 \mu$, activity $1.5 \mathrm{kBq}$, specific activity $2.28 \mathrm{GBq} \mathrm{mmol}^{-1}$ ) was injected into each tube. The tubes were stored horizontally and gently shaken for $5 \mathrm{~d}$ at $12^{\circ} \mathrm{C}$. After incubation, the sediment slurry/seawater medium was transferred into $50-\mathrm{ml}$ glass vials filled with $25 \mathrm{ml}$ sodium hydroxide $(2.5 \% \mathrm{w} / \mathrm{w})$ and closed with rubber stoppers. Further analysis was the same as for ${ }^{14} \mathrm{C}$ AOM samples described above.

Methane production-The production of methane was measured in vitro in the absence of sulfate, as described by Krüger et al. (2001). Three cubic centimeters of sediment slurry were transferred into sterile glass tubes as described above. Nine milliliters of sulfate-free artificial seawater medium were added and the tubes were sealed with butyl rubber stoppers. The tubes were repeatedly flushed with $\mathrm{N}_{2} / \mathrm{CO}_{2}$ mixture $(90 / 10 \mathrm{vol} / \mathrm{vol})$ to remove residual methane in the slurry. The final headspace in the tube was also a $\mathrm{N}_{2} / \mathrm{CO}_{2}$ mixture $(90 / 10 \mathrm{vol} / \mathrm{vol})$. Incubation was the same as described for potential AOM. The incubation temperature was $12^{\circ} \mathrm{C}$. Headspace samples $(0.1 \mathrm{ml})$ were taken with pressure lock syringes twice per day, after shaking of the tubes by hand, and analyzed for methane.

Potential aerobic oxidation of methane (aerobic MO) Potential aerobic MO was determined in vitro according to Krüger et al. (2002). Sediment slurries were produced under oxic conditions. The slurries $\left(20 \mathrm{~cm}^{3}\right)$ were transferred into sterile glass bottles $(175 \mathrm{ml})$ and sealed with butyl rubber stoppers. The oxic headspace was supplemented with 10,000 $\operatorname{ppm}_{\mathrm{v}}$ methane. The bottles were incubated at $12^{\circ} \mathrm{C}$ in the dark and shaken once per day. Methane depletion was followed by sampling the headspace from triplicate incubations, after thoroughly shaking the bottles, and subsequent gas chromatography. The first sample was taken $30 \mathrm{~min}$ after the amendment with methane, followed by sampling at 24$\mathrm{h}$ intervals. Linear regressions were calculated from the mean methane depletion curves to obtain the aerobic MO rates.

Identification of microorganisms by fuorescence in situ hybridization (FISH) - For sediment measurements, a push core was sectioned at $1-\mathrm{cm}$ intervals. For slurry measurements, aliquots of the sediment slurries were taken. One cubic centimeter of each sediment slice or sediment slurry was transferred into $3 \mathrm{ml}$ formaldehyde (final concentration 3\%) and fixed for 2-3 h. After fixation, the sample was washed twice with $1 \times$ PBS $\left(10 \mathrm{mmol} \mathrm{L}^{-1}\right.$ sodium phosphate, 130 $\left.\mathrm{mmol} \mathrm{L}{ }^{-1} \mathrm{NaCl}\right)$ and finally stored in $1 \times \mathrm{PBS} / \mathrm{EtOH}(1: 1)$ at $-25^{\circ} \mathrm{C}$. Fixed samples were diluted $(1: 10)$ with PBS and treated by mild sonication for $20 \mathrm{~s}$ with a MS73 probe (Sonoplus HD70) at an amplitude of $42 \mu \mathrm{m}<10 \mathrm{~W}$. An aliquot (40 $\mu \mathrm{l})$ was filtered on $0.2-\mu \mathrm{m}$ GTTP polycarbonate filters (Millipore). The filters were embedded in low-gelling-point agarose. Hybridization and microscopic counts of hybridized and 4',6'-diamidino-2-phenylindole (DAPI)-stained cells were performed as described previously (Snaidr et al. 1997). Mean values of aggregate numbers were calculated by using 200-400 randomly chosen fields of view for each filter section, corresponding to 700-1,200 hybridized cells. Means of total free-living cells were calculated by using 16-17 randomly chosen fields of view for each filter section, corresponding to 700-1,000 DAPI-stained cells. Cy3- and Cy5monolabeled oligonucleotides were purchased from ThermoHybaid. Probes and formamide (FA) concentrations used in this study were as follows: EeelMS932 targeting ANME-2 (Hinrichs et al. 1999, 40\% FA), ANME-1 targeting ANME-1 (Hinrichs et al. 1999, 40\% FA), EUB338-targeting bacteria (Amann et al. 1990, 40\% FA in double hybridization with EeelMS932), DSS658 targeting Desulfosarcina spp./ Desulfococcus spp./Desulfofrigus spp. and Desulfofaba spp. (Manz et al. 1998, 40\% FA in double hybridization with ANME-2, 60\% FA in single hybridization). To avoid background signals, $10 \%$ blocking reagent (Roche) was added to hybridization buffers (20\% vol/vol).

\section{Results}

Hydrographic conditions - In early September, the water column at Sta. A (Fig. 2a-c) was clearly stratified into a cold, saline bottom layer and a warm, freshwater-influenced 
surface layer. Temperature decreased from $17^{\circ} \mathrm{C}$ at the surface to $10^{\circ} \mathrm{C}$ at the bottom. Salinity was lower at the surface (salinity 15) compared with the bottom water (salinity 23). After the first autumn storm, a partial mixing of the water layers decreased surface temperatures to $15^{\circ} \mathrm{C}$ and caused an increase to $11^{\circ} \mathrm{C}$ at the bottom. Salinity increased to 17 at the surface and a halocline was formed at $5.6 \mathrm{~m}$. At the bottom, salinity stayed constant. During winter, the water column was completely mixed and both temperature $\left(4^{\circ} \mathrm{C}\right)$ and salinity (20) were constant with depth in March.

At Sta. B (Fig. 3a-c), the stratification of the water column during early September was similar to Sta. A, with a warm surface layer of $17^{\circ} \mathrm{C}$ and a salinity of 15 and a colder bottom water of $10^{\circ} \mathrm{C}$ and a salinity of 23 . The mixing of the water column after the storm was slightly more pronounced, resulting in $14^{\circ} \mathrm{C}$ and a salinity of 19 at the surface and $11^{\circ} \mathrm{C}$ and a salinity of 23 at the bottom. In March, temperature $\left(4^{\circ} \mathrm{C}\right)$ and salinity $(20)$ were homogeneous with depth.

Chemistry and ex-situ process rates-Sediment description: At Sta. A, the surface of sediment cores was graygreenish and very fluffy, with a porosity of up to 0.92 . This sediment type reached a depth of 3 to $4 \mathrm{~cm}$, below which black sediment was found. The black sediment had a porosity of about 0.86 and smelled strongly of hydrogen sulfide. During the late September and March sampling, the sediment surface was strongly resuspended, most likely as a consequence of stormy weather. In late September, the turbulent disturbance of the sediment surface was documented in situ with a deployed camera system (Karpen 2002).

At Sta. B, the sediment had the same fluffy consistency and porosity as Sta. A. However, in early and late September, the sediment was completely black, with a strong smell of hydrogen sulfide. In March, the sediment was also strongly resuspended and the upper $4 \mathrm{~cm}$ had turned brown. Filaments of the sulfur-oxidizing bacteria (Beggiatoa) were visible at the sediment surface in early and late September. They occurred at the subsurface in March, as demonstrated by microscopic investigation (A. Preisler, pers. comm.).

Sulfate and methane-At Sta. A, sulfate and methane concentrations (Fig. 2d-f) in the sediment varied between September and March. The decrease in sulfate over depth was steepest in September, with a penetration depth of approximately $23 \mathrm{~cm}$, and lowest in March, resulting in the deepest penetration of approximately $32 \mathrm{~cm}$. In the topmost layer of the sediment $(0-1 \mathrm{~cm})$, sulfate concentration was highest in early September $\left(21.4 \mathrm{mmol} \mathrm{L}^{-1}\right)$ and lowest in March (16.0 mmol L $\left.{ }^{-1}\right)$. The lowered sulfate concentration in March is in accordance with the decrease in bottom-water salinity (see previous). Methane was nearly zero at the sediment surface (between 0.001 and $0.010 \mathrm{mmol} \mathrm{L}^{-1}$ ) and increased to values between 0.2 and $0.8 \mathrm{mmol} \mathrm{L}^{-1}$ toward the bottom of the cores. The methane gradient was highest in March and lowest in early September.

At Sta. B (Fig. 3d-f), the variations of sulfate and methane concentration were similar to Sta. A. The decrease in sulfate over depth was steepest in September, with a penetration of approximately $25 \mathrm{~cm}$, and lowest in March, resulting in the deepest penetration depth of approximately $33 \mathrm{~cm}$. In the topmost layer of the sediment $(0-1 \mathrm{~cm})$, sulfate concentration was highest in early September (21.9) and lowest in March $\left(16.5 \mathrm{mmol} \mathrm{L}^{-1}\right)$. In all measurements, methane was near zero in the topmost layer (between 0.003 and 0.014 mmol L ${ }^{-1}$ ) and increased to values between 0.3 and 1.6 mmol L-1 at the bottom of the cores. The methane gradient was highest in late September and lowest in early September.

Anaerobic oxidation of methane (AOM) - In early September, AOM at Sta. A (Fig. $2 \mathrm{~g}-\mathrm{i}$ ) was detectable over the whole depth interval investigated $(24 \mathrm{~cm})$. In the upper 20 $\mathrm{cm}$, rates varied between 0.5 and $7 \mathrm{nmol} \mathrm{cm}{ }^{-3} \mathrm{~d}^{-1}$ without a clear peak. In the deeper part $(21-23 \mathrm{~cm})$, rates were high-

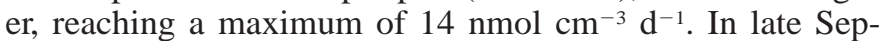
tember, the zone of elevated rates moved slightly upward into depths between 17 and $22 \mathrm{~cm}$. The activity close to the surface $(0-3 \mathrm{~cm})$ was reduced to $1 \mathrm{nmol} \mathrm{cm}-3 \mathrm{~d}^{-1}$, reaching a minimum (mean value $0.03 \mathrm{nmol} \mathrm{cm} \mathrm{cm}^{-3} \mathrm{~d}^{-1}$ ) in the 0 - to $1-\mathrm{cm}$ interval. In March, AOM was reduced to less than 1 nmol cm$~^{-3} \mathrm{~d}^{-1}$ between 0 and $15 \mathrm{~cm}$. The lowest activity was found in the 0 - to $1-\mathrm{cm}$ interval (mean value $0.07 \mathrm{nmol}$ $\mathrm{cm}^{-3} \mathrm{~d}^{-1}$ ). Below $15 \mathrm{~cm}$, AOM increased steadily and reached $10 \mathrm{nmol} \mathrm{cm}^{-3} \mathrm{~d}^{-1}$ between 23 and $24 \mathrm{~cm}$. Integrated over 0-25 cm, AOM activity was highest in early September $\left(0.93 \mathrm{mmol} \mathrm{m}^{-2} \mathrm{~d}^{-1}\right)$ and decreased to $0.48 \mathrm{mmol} \mathrm{m}^{-2} \mathrm{~d}^{-1}$ in March (Table 1).

At Sta. B (Fig. 3g-i), AOM activity in early September was also detectable over the whole core. In the upper $20 \mathrm{~cm}$, rates varied between 2 and $5 \mathrm{nmol} \mathrm{cm}{ }^{-3} \mathrm{~d}^{-1}$. In the deeper part $(20-25 \mathrm{~cm})$, rates were elevated, reaching a maximum of $13 \mathrm{nmol} \mathrm{cm}^{-3} \mathrm{~d}^{-1}$. In late September, AOM showed a distinct maximum in the middle of the core (mean value 11 $\mathrm{nmol} \mathrm{cm} \mathrm{cm}^{-3} \mathrm{~d}^{-1}$ at $14-15 \mathrm{~cm}$ ) and decreased toward the upper and lower end of the core (mean values $0.03 \mathrm{nmol} \mathrm{cm}^{-3} \mathrm{~d}^{-1}$ at $0-1 \mathrm{~cm}$ and $1.22 \mathrm{nmol} \mathrm{cm}^{-3} \mathrm{~d}^{-1}$ at $24-25 \mathrm{~cm}$ ). In March, AOM was reduced to less than $2.5 \mathrm{nmol} \mathrm{cm}^{-3} \mathrm{~d}^{-1}$ between 0 and $15 \mathrm{~cm}$. Below $15 \mathrm{~cm}, \mathrm{AOM}$ increased steadily up to $9 \mathrm{nmol} \mathrm{cm}{ }^{-3} \mathrm{~d}^{-1}$ at $22-23 \mathrm{~cm}$. Integrated over $0-25 \mathrm{~cm}$, AOM activity was highest in late September $\left(1.50 \mathrm{mmol} \mathrm{m}^{-2}\right.$ $\mathrm{d}^{-1}$, Table 1).

Test for differences in AOM between investigated seasons-For the analysis of differences in the rate and distribution of AOM between early September, late September, and March at Sta. A and B, respectively, a paired-sample $t$ test was applied. AOM values of each season were divided into 5-cm depth intervals $(0-5 \mathrm{~cm}, 5-10 \mathrm{~cm}, 10-15 \mathrm{~cm}$, etc.), corresponding to a total number of $n=15$ values per interval (three replicates per $\mathrm{cm}$ multiplied by five). Each depth interval of a season was tested against the respective depth interval of another season (early September vs. late September, late September vs. March, March vs. early September). $p$-values were determined and, $p<0.05$ AOM of the compared intervals was considered to differ significantly. AOM of the $20-$ to $25-\mathrm{cm}$ interval revealed no significant changes between seasons at both stations. Nearly all seasons revealed highly significant changes of AOM $(p<0.005)$ between 5 and $20 \mathrm{~cm}$. The only exception was early versus late September at Sta. A, where no significant changes were 

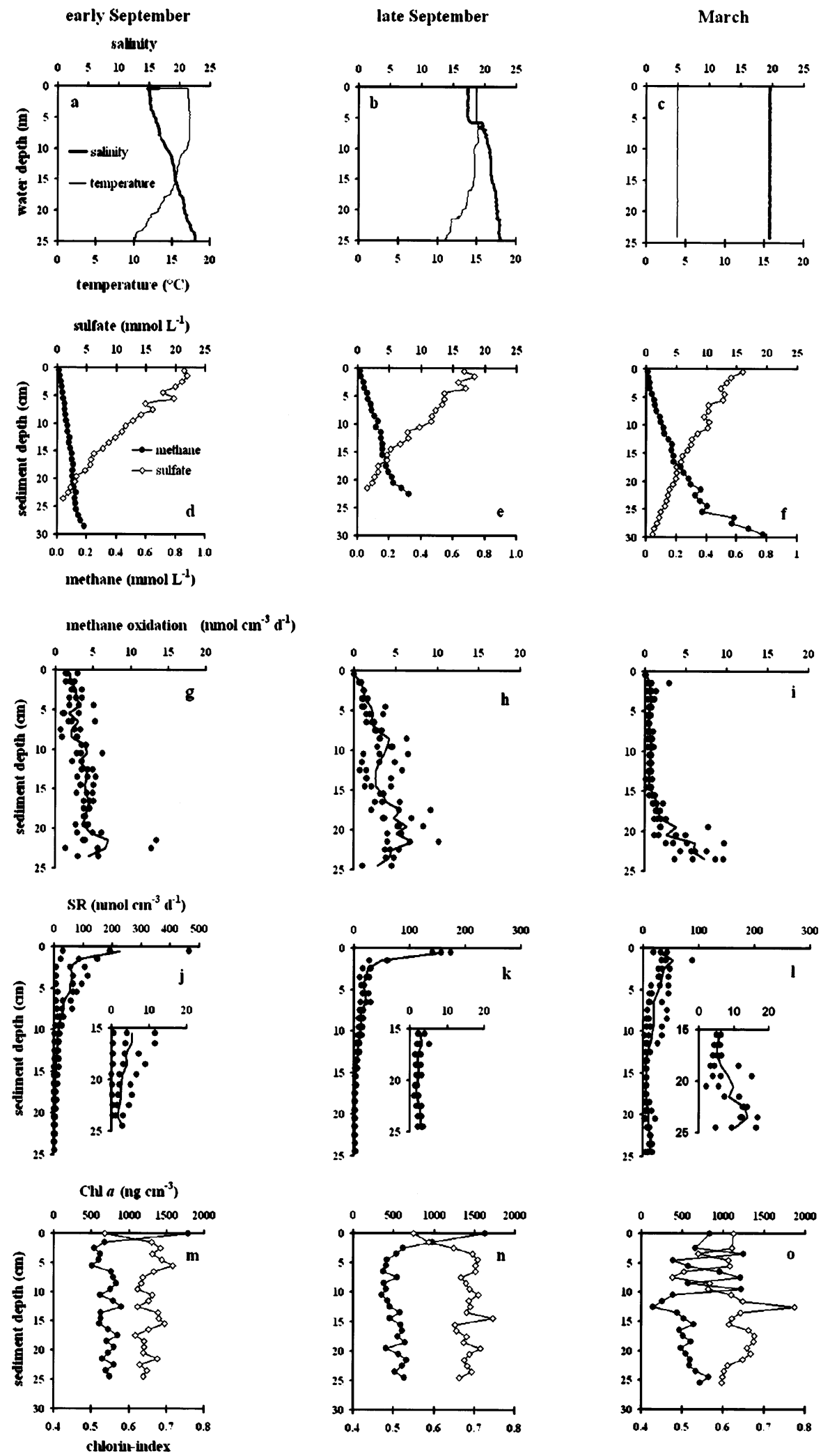

Fig. 2. (a-o). Parameters measured at Sta. A. Chl $a$ concentration $=$ solid circles, chlorin index $=$ open rhomb. SR of deeper sediment parts is given in higher resolutions (small insert). 

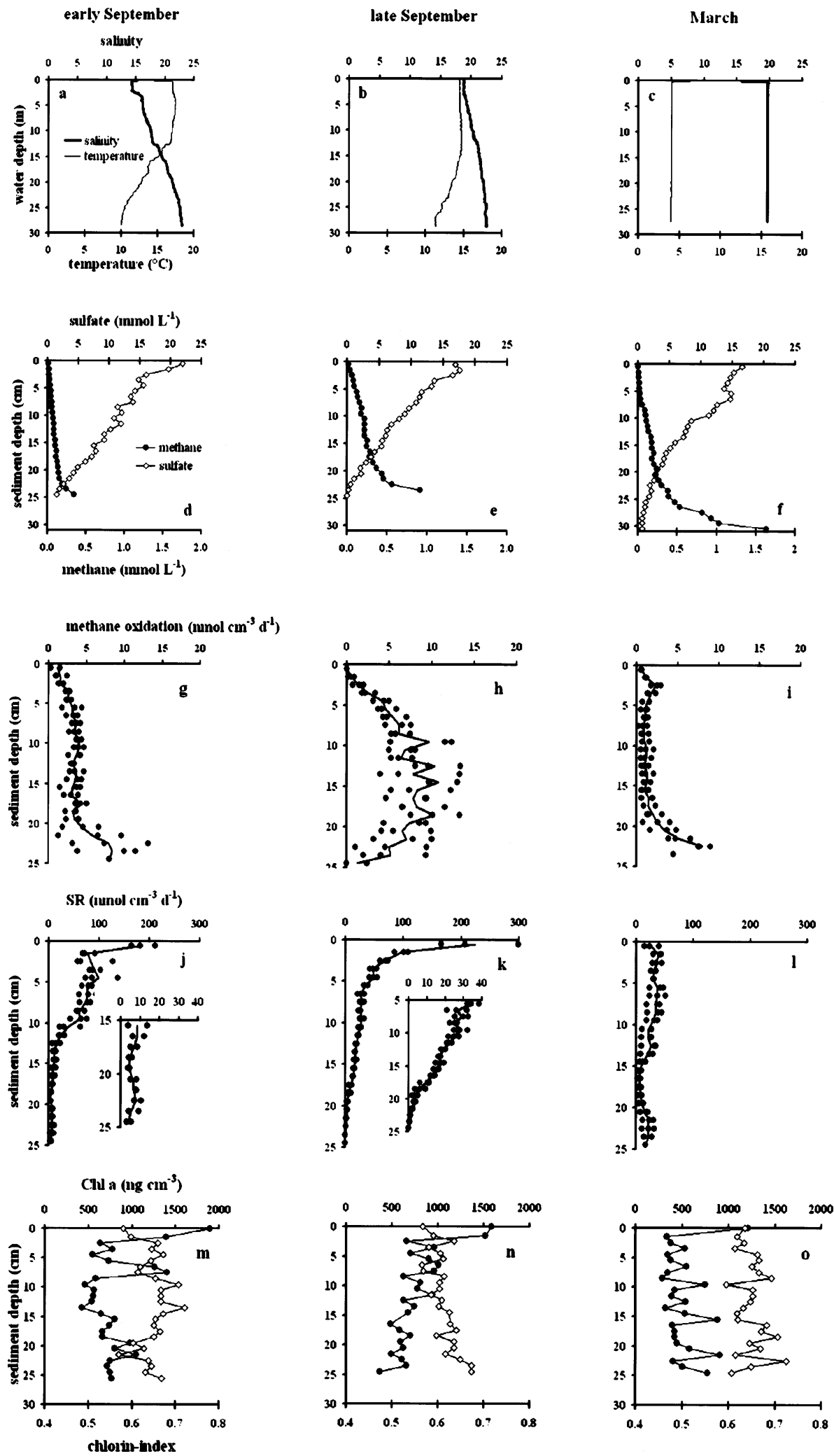

Fig. 3. (a-o). Parameters measured at Sta. B. Chl $a$ concentration $=$ solid circles, chlorin index $=$ open rhomb. SR of deeper sediment parts is given in higher resolutions (small insert). 
Table 1. Rates of AOM and SR as well as chlorophyll $a$ concentration per $\mathrm{m}^{2}$ (integrated over $0-25 \mathrm{~cm}$ ). Standard deviations of $\mathrm{AOM}$ and SR are givin in parenthesis.

\begin{tabular}{lccc}
\hline \hline & $\begin{array}{c}\mathrm{AOM}^{*} \\
\left(\mathrm{mmol} \mathrm{m}^{-2} \mathrm{~d}^{-1}\right)\end{array}$ & $\begin{array}{c}\mathrm{SR} \\
\left(\mathrm{mmol} \mathrm{m}^{-2} \mathrm{~d}^{-1}\right)\end{array}$ & $\begin{array}{c}\mathrm{Chl} \\
a\left(\mathrm{mg} \mathrm{m}^{2}\right)\end{array}$ \\
\hline Sta. A & & & \\
$\quad$ Early Sep & $0.93( \pm 0.36)$ & $7.3( \pm 6.1)$ & 187 \\
Late Sep & $0.83( \pm 0.35)$ & $4.1( \pm 1.0)$ & 143 \\
Early Mar & $0.48( \pm 0.19)$ & $4.2( \pm 2.4)$ & 160 \\
Sta. B & & & \\
Early Sep & $0.96( \pm 0.31)$ & $10.5( \pm 2.5)$ & 203 \\
Late Sep & $1.50( \pm 0.56)$ & $7.8( \pm 1.4)$ & 198 \\
Early Mar & $0.51( \pm 0.15)$ & $5.6( \pm 2.0)$ & 130 \\
\hline
\end{tabular}

* Presumable aerobic rates are excluded.

found. At Sta. A, methane oxidation of the 0- to 5-cm interval was significantly different $(p<0.05)$ between all seasons. At Sta. B, no significant changes were found in the 0 to 5 -cm interval.

Sulfate reduction (SR)—At Sta. A (Fig. $2 \mathrm{j}-1$ ), SR was always highest close to the sediment surface, with rates reaching up to $465 \mathrm{nmol} \mathrm{cm}^{-3} \mathrm{~d}^{-1}$ in early September. Most of the SR was restricted to the upper $10 \mathrm{~cm}$ of the sediment. Between early September and March, rates decreased to values between 20 and $90 \mathrm{nmol} \mathrm{cm} \mathrm{cm}^{-3} \mathrm{~d}^{-1}$ in the upper sediment. Integrated over $0-25 \mathrm{~cm}$, SR activity was highest in early September, with $7.3 \mathrm{mmol} \mathrm{m}^{-2} \mathrm{~d}^{-1}$, and around $4 \mathrm{mmol} \mathrm{m}^{-2}$ $\mathrm{d}^{-1}$ during the later season (Table 1).

At Sta. B, SR (Fig. 3j-1) of early and late September was highest in the top layer, reaching a maximum of $224 \mathrm{nmol}$ $\mathrm{cm}^{-3} \mathrm{~d}^{-1}$ in late September. As for Sta. A, the majority of SR activity was restricted to the upper $10 \mathrm{~cm}$ of the sediment at all times. Between early September and March, rates de-

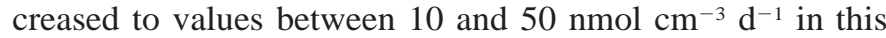
most active zone. Integrated over $0-25 \mathrm{~cm}$, SR activity was highest in early September, with $10.5 \mathrm{mmol} \mathrm{m}^{-2} \mathrm{~d}^{-1}$, and decreased to $5.6 \mathrm{mmol} \mathrm{m}^{-2} \mathrm{~d}^{-1}$ in March (Table 1).

Comparing the three replicates of SR with those of AOM for each depth interval (1-cm steps) within the sulfate-methane transition zones $(15-25 \mathrm{~cm}$, see small cutouts in SR profiles of Figs. 2 and 3) with a paired-sample $t$-test, the majority of the AOM and SR rates $(75 \%)$ agreed well $(p>$ 0.05 ). In $11 \%$ of the cases, SR exceeded AOM (mean SR: AOM ratio $=10: 3$ ), and in $14 \%$ of the cases, AOM exceeded SR (mean AOM :SR ratio $=5: 2$ ). The discrepancies might be a result of methodological issues, e.g., methane losses or different treatments of AOM and SR samples. Higher SR rates might be due to the use of substrates other than methane by the sulfate-reducing community.

Chlorophyll a and chlorin index-At Sta. A (Fig. 2m-o), the deposition of fresh algal material on the sediment surface, as measured by $\mathrm{Chl} a$ concentrations, was highest in

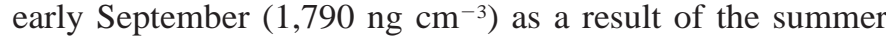
phytoplankton sedimentation (Bodungen 1975). This increase in fresh organic matter, which is also confirmed by a low chlorin index of 0.53 , was restricted to the 0 - to $1-\mathrm{cm}$ layer of the sediment. Below that layer, $\mathrm{Chl} a$ concentrations stayed around $700 \mathrm{ng} \mathrm{cm}^{-3}$, while the chlorin index increased to around 0.66 as a result of the advancing decomposition. In late September, the picture was similar but the elevated Chl $a$ concentration reached a depth of $2 \mathrm{~cm}$. The downward mixing could have been caused by resuspension during stormy weather or by bioturbation. It is also possible that patchy deposition of organic matter is causing a lateral heterogeneity of chlorophyll concentrations in the sediment. Over the winter, fresh organic matter appeared to be buried deeper into the sediment, leading to reduced $\mathrm{Chl} a$ concentrations in the 0 - to $1-\mathrm{cm}$ layer $\left(831 \mathrm{ng} \mathrm{cm}^{-3}\right)$ and irregular profiles with maxima of up to $1,250 \mathrm{ng} \mathrm{cm}^{-3}$ in the top 10 $\mathrm{cm}$ of the sediment. Consequently, the chlorin index showed an inverse profile. Integrated over $25 \mathrm{~cm}$ (Table 1), Chl $a$ concentrations were similar for all seasons investigated.

At Sta. B, the deposition of fresh algal material (Fig. 3mo) onto the sediment was also highest in early September $\left(1,895 \mathrm{ng} \mathrm{cm}^{-3}\right.$ in the 0 - to 1 -cm layer) and revealed peaks between 0 and $2 \mathrm{~cm}$ as well as between 6 and $8 \mathrm{~cm}$. The deeper peak represents, most likely, old buried material. This is confirmed by the chlorin index revealing higher values (0.62) in the deeper peak compared with the surface (0.59), i.e., the proportion of degraded organic matter was larger in the deeper fraction. Below the peaks, the sediment had Chl $a$ values around $700 \mathrm{ng} \mathrm{cm}^{-3}$, with a chlorin index of about 0.65. In late September, the deeper peak was not found again, which could be either a consequence of degradation processes or lateral heterogeneity. Chl $a$ concentrations were elevated only at the surface (around 1,500 $\mathrm{ng} \mathrm{cm}^{-3}$ between 0 and $2 \mathrm{~cm}$ ). Below the surface, Chl $a$ decreased steadily from 1,000 to $360 \mathrm{ng} \mathrm{cm}^{-3}$. The chlorin index showed an inverse profile, with lowest values at the surface (0.57) and highest at the bottom of the core (0.67). In March, there was still a peak of Chl $a$ at the topmost layer $\left(1,213 \mathrm{ng} \mathrm{cm}^{-3}\right)$, but the high chlorin index (0.64) shows that a larger fraction of the algal material was already degraded. The deeper part of the sediment revealed a Chl $a$ concentration around 500 $\mathrm{ng} \mathrm{cm} \mathrm{cm}^{-3}$ and a chlorin index of about 0.65 . Integrated over $25 \mathrm{~cm}$ (Table 1), Chl $a$ in March was only $60 \%$ of the concentration in early September.

In vitro process rates-Potential AOM: Averaged potential rates fluctuated between 20 and $90 \mathrm{nmol} \mathrm{cm}^{-3} \mathrm{~d}^{-1}$ in both seasons (Fig. 4). Within the top $30 \mathrm{~cm}$, no clear trend was visible and the seasons yielded different profiles. In March, when the sampling depth was expanded to $40 \mathrm{~cm}$, a decrease of AOM was measured below $30 \mathrm{~cm}$.

Temperature optimum of AOM: Temperature-dependent potential AOM (25-30 cm, early September, Fig. 5) revealed highest rates at $20^{\circ} \mathrm{C}\left(97 \mathrm{nmol} \mathrm{cm} \mathrm{cm}^{-3} \mathrm{~d}^{-1}\right)$, characterizing the responsible organisms as mesophilic (Madigan et al. 2000). The rates increased steadily from $4^{\circ} \mathrm{C}\left(29 \mathrm{nmol} \mathrm{cm}{ }^{-3} \mathrm{~d}^{-1}\right)$ to $20^{\circ} \mathrm{C}$. At $28^{\circ} \mathrm{C}$, AOM decreased to $87 \mathrm{nmol} \mathrm{cm} \mathrm{cm}^{-3} \mathrm{~d}^{-1}$.

AOM inhibition by oxygen: ${ }^{14} \mathrm{CO}_{2}$ production in incubations with oxic sediment slurry was not significantly different from production in incubations with artificial seawater (negative controls). Therefore, AOM activity was considered 


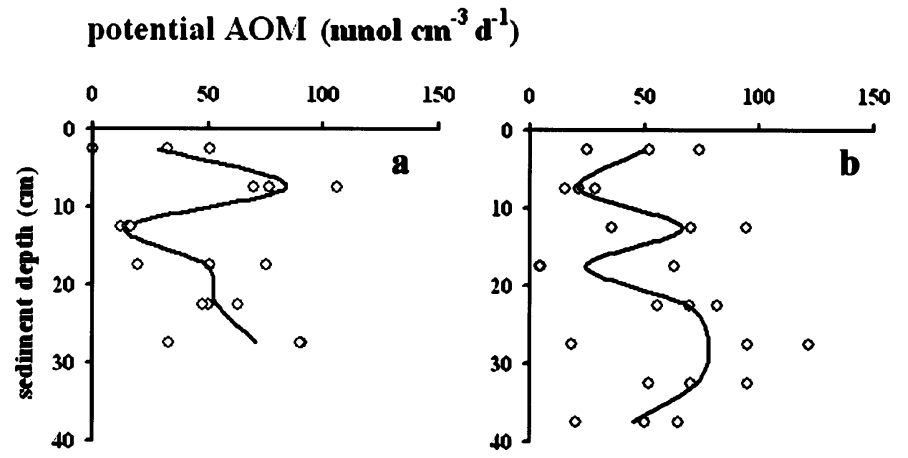

Fig. 4. Potential AOM in sediment slurries of Sta. B taken in (a) early September and (b) March (mean of three replicates shown as solid line).

to be zero in the presence of oxygen. In anoxic incubations, the ${ }^{14} \mathrm{CO}_{2}$ production was significantly higher compared with negative controls, resulting in an average AOM rate of 25.4 $\mathrm{nmol} \mathrm{cm} \mathrm{cm}^{-3} \mathrm{~d}^{-1}( \pm 8.1$ standard deviation $[\mathrm{SD}])$.

Coupling of AOM and SR: ${ }^{14} \mathrm{CO}_{2}$ production in incubations with sediment slurries (both with and without addition of molybdate) differed significantly from incubations with artificial seawater, i.e., revealing AOM activity. However, the AOM activity in sediment slurries with added molybdate $\left(32.8 \mathrm{nmol} \mathrm{cm}^{-3} \mathrm{~d}^{-1}, \pm 11.4 \mathrm{SD}\right)$ was only $27 \%$ of the AOM activity measured in sediment slurries without molybdate (119.1 $\left.\mathrm{nmol} \mathrm{cm}^{-3} \mathrm{~d}^{-1}, \pm 29.3 \mathrm{SD}\right)$. AOM was therefore significantly reduced after the inhibition of SR, demonstrating the close coupling between the two processes in Eckernförde Bay sediments.

Methane production: The rates increased with depth in both seasons (Fig. 6). No considerable methane production was detected in the top section $(0-5 \mathrm{~cm})$. In early September, rates were lower compared with respective depth sections of March. In early September, methanogenesis reached a maximum of $9.8 \mathrm{nmol} \mathrm{cm} \mathrm{cm}^{-3} \mathrm{~d}^{-1}$ between 25 and $30 \mathrm{~cm}$ (the maximum sampling depth). In March, a maximum of 37 nmol cm $\mathrm{cm}^{-3} \mathrm{~d}^{-1}$ was reached between 30 and $35 \mathrm{~cm}$.

Potential aerobic MO: Potential aerobic MO was 9.1 $( \pm 2.5 \mathrm{SD}) \mathrm{nmol} \mathrm{cm} \mathrm{cm}^{-3} \mathrm{~d}^{-1}$ in early September and $4.6( \pm 3.4$ SD) $\mathrm{nmol} \mathrm{cm} \mathrm{cm}^{-3} \mathrm{~d}^{-1}$ in March for the section 0-5 cm. At 5to $10-\mathrm{cm}$ depth, aerobic MO was not detected.

Identification of microorganisms with fluorescence in situ hybridization (FISH) - Slurries $(0-10 \mathrm{~cm}$ and $25-25 \mathrm{~cm}$, early September) as well as sediment from the depth of the highest detected AOM rates (Sta. A: 21-22 cm, early September; 23-24 cm, late September; 24-25 cm, March; Sta. B: $19-20 \mathrm{~cm}$, early September; $14-15 \mathrm{~cm}$, late September; 24-25 cm, March) were investigated with FISH. In all samples, abundant cell aggregates were detected by the EelMS932 probe targeting archaea of the ANME-2 cluster (Fig. 7). Archaea of this cluster are reported to mediate AOM in syntrophic consortia with sulfate-reducing bacteria of the branch Desulfococcus/Desulfosarcina (Boetius et al.

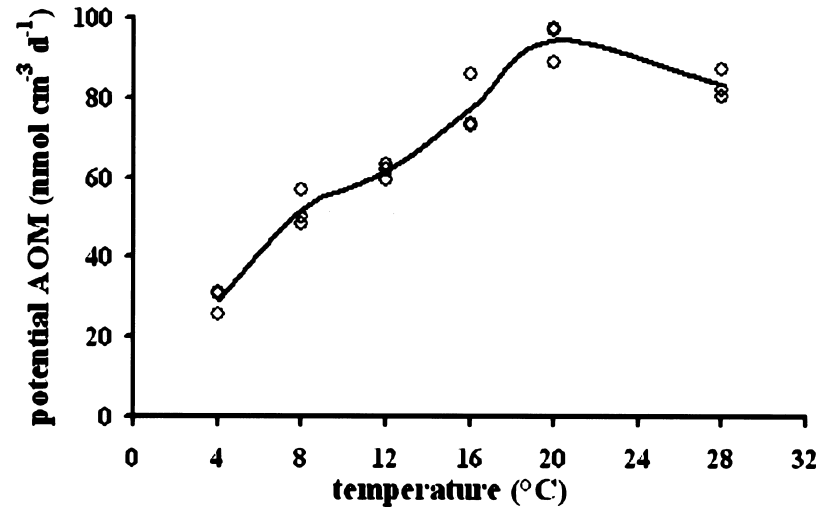

Fig. 5. Temperature correlation of potential AOM in sediment slurries $(25-30 \mathrm{~cm}$ ) of Sta. B taken in early September (mean of three replicates shown as solid line).

2000). The ANME-2 aggregates found in the Eckernförde Bay sediments had no apparent syntrophic partner. In EelMS932 (CY3)/DSS658 (CY5) or EelMS932 (CY3)/ EUB338 (CY5) double-hybridizations (Fig. 7a,c), the cells of the aggregates were targeted only by EelMS932. Control analysis of the DAPI signal also revealed no additional cells than those accounted for by EelMS932 (Fig. 7b). Preliminary aggregate counts of the depth interval $24-26 \mathrm{~cm}$ of the March sampling revealed an ANME-2 aggregate density of 1.12 and $0.95 \times 10^{6} \mathrm{~cm}^{-3}$ for Sta. A and B, respectively. This corresponds to a cell density of 3.8 and $5.1 \times 10^{7} \mathrm{~cm}^{-3}$, respectively (Table 2 ). The coccoid cells had a diameter of about $0.7 \mu \mathrm{m}$. The largest aggregates reached a diameter of 6-8 $\mu \mathrm{m}$ with cell numbers between 300 and 500. However, the majority of the aggregates (93\%) had lower cell numbers with an average of $22 \pm 22$ mean deviation (MD) $(n=43$, Fig. 7d,e). In some cases, the cells occurred in pairs (Fig. $7 \mathrm{f}, \mathrm{g})$. No single cells were found. ANME-2 aggregates comprised $21 \%$ and $28 \%$ of the total microbial cell numbers at Sta. A and B, respectively. Other archaeal cells in the sediment were detected by the ANME-1 probe targeting cells of the ANME-1 cluster, archaea also known to be responsible for AOM (Michaelis et al. 2002). The cells revealed a rectangular shape, as it is typically for ANME-1, and occurred in short chains of 4-6 cells. Their abundance was too low for quantification (only 2 or 3 chains were found per filter

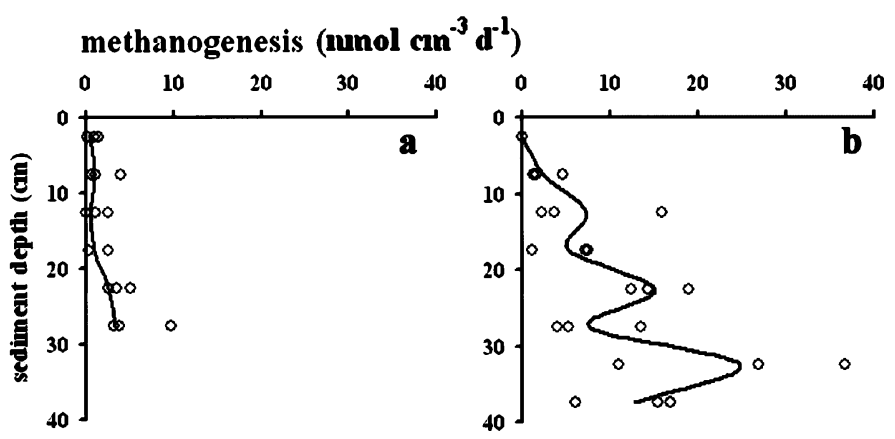

Fig. 6. Methanogenesis in sulfate-free sediment slurries of Sta. B taken in (a) early September and (b) March (mean of three replicates shown as solid line). 


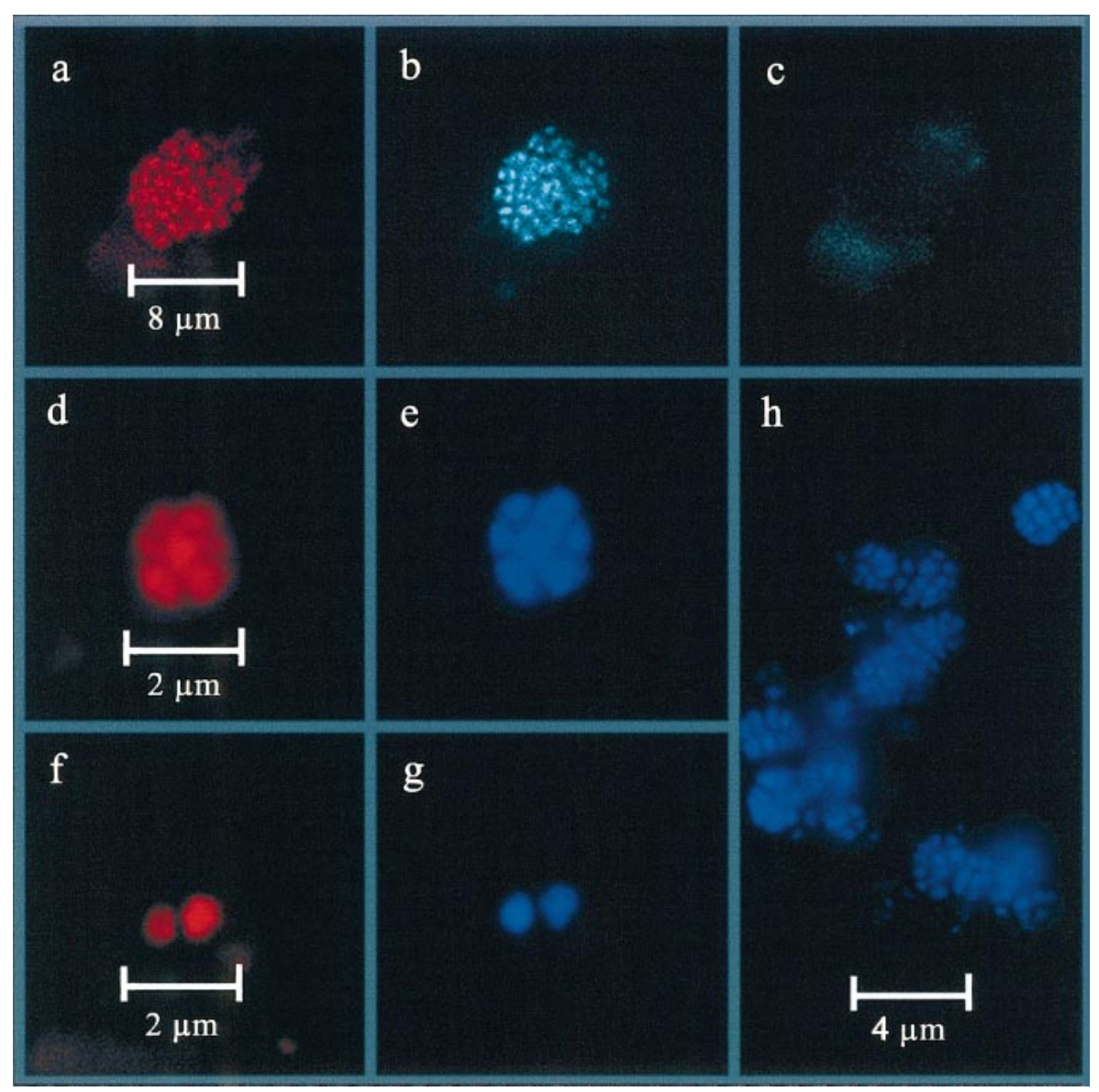

Fig. 7. (a-h). In situ identification of ANME-2 aggregates with fluorescently labeled rRNAtargeted oligonucleotide probes. (a-c) Confocal laser scanning micrograph of the hybridization with the CY3-labelled EelMS932 (a, shown in red), the DAPI staining (b, shown in blue), and the hybridization with the CY5 labeled EUB338 (c, shown in green). (d/e, f/g) Epifluorescence micrographs of a small aggregate and a two-cell-stage hybridized with the CY3 labeled EelMS932 (d and $\mathrm{f}$ ) and stained with DAPI (e and g). (h) Accumulation of DAPI-stained aggregates.

analyzed). Specimen of the assumed syntrophic ANME-2 partner, i.e., sulfate-reducing bacteria of the branch Desulfococcus/Desulfosarcina (targeted by probe DSS658), were also abundant in the sediment but occurred only as single cells or in aggregates without archaeal partners. The coccoid cells had a diameter of about $0.5 \mu \mathrm{m}$. Preliminary cell counts of the depth interval 24-26 cm of the March samplings revealed a Desulfococcus/Desulfosarcina aggregate density of 5.1 and $6.7 \times 10^{5} \mathrm{~cm}^{-3}$ for Sta. A and $\mathrm{B}$, respectively. This

Table 2. Preliminary cell numbers of EelMS932 (ANME-2) and DSS658 targeted cells. Single cell numbers were determined by counting DAPI stained, nontargeted cells.

\begin{tabular}{|c|c|c|c|}
\hline & $\begin{array}{c}\text { ANME-2 } \\
\left(\text { cells } \mathrm{cm}^{-3}\right)\end{array}$ & $\begin{array}{c}\text { DSS658 } \\
\left(\text { cells } \mathrm{cm}^{-3}\right)\end{array}$ & $\begin{array}{l}\text { Single cells } \\
\left(\text { cells } \mathrm{cm}^{-3}\right)\end{array}$ \\
\hline \multicolumn{4}{|l|}{ Sta. A } \\
\hline $24-26 \mathrm{~cm}$ & $3.8 \times 10^{7}$ & $3.4 \times 10^{6}$ & $1.4 \times 10^{8}$ \\
\hline \multicolumn{4}{|l|}{ Sta. B } \\
\hline $24-26 \mathrm{~cm}$ & $5.1 \times 10^{7}$ & $5.1 \times 10^{6}$ & $1.2 \times 10^{8}$ \\
\hline
\end{tabular}

corresponds to a cell density of 3.4 and $5.1 \times 10^{6} \mathrm{~cm}^{-3}$, respectively (Table 2). Therefore, the ratio between ANME2 and Desulfococcus/Desulfosarcina cells in the sediment was about $10: 1$ at both stations. The aggregates of Desulfococcus/Desulfosarcina were smaller compared with ANME-2. The largest ones comprised between 30 and 44 cells. The majority of the aggregates $(91 \%)$ had lower cell numbers, with an average of $3 \pm 1 \mathrm{MD}(n=31)$. Also, single cells were found.

It should be mentioned that the cell counts may represent underestimations, as the dilution of the sediment was chosen relatively low to obtain an appropriate number of aggregates per filter. Thus, the sediment formed more than one layer on the filter and could have hidden cells. However, the underestimation should be similar for ANME-2 and Desulfococcus/Desulfosarcina cells due to their similar cell size and aggregate properties.

\section{Discussion}

Organisms apparently mediating AOM in Eckernförde Bay-The sediments of Eckernförde Bay contained abun- 
dant aggregates belonging to the Methanosarcinales-related ANME-2 cluster. Archaea of this cluster have been described to mediate AOM in consortia with sulfate-reducing bacteria of the Desulfococcus/Desulfosarcina branch in different methane-bearing sediments in the North Pacific (Boetius et al. 2000; Orphan et al. 2001a,b). In contrast with those sites, the ANME-2 aggregates in Eckernförde Bay never had bacterial partners. Monospecific aggregates of ANME-2 were already described (Orphan et al. 2001b), but they were found only occasionally in sediments dominated by ANME-2/Desulfococcus/Desulfosarcina consortia. These findings raise the question whether methane-oxidizing archaea need to interact with sulfate-reducing bacteria. Although monospecific aggregates of Desulfococcus/Desulfosarcina were also found in the sediments of Eckernförde Bay, their abundance was 10 times lower compared with ANME-2 aggregates. Moreover, AOM based on a loose co-occurrence of archaeal and bacterial cells in the sediment is not likely to provide an efficient syntrophy because a close cell-to-cell contact is hypothesized to be needed for a transfer of metabolic intermediates (Sørensen et al. 2001). Because FISH offers no information about the physiology of an organism, however, we can only speculate from their high abundance and close relationship to known AOM organisms that the ANME-2 aggregates are responsible for the methane consumption in Eckernförde Bay.

The temperature optimum of AOM in Eckernförde Bay sediments indicates another physiological difference from other known anaerobic methane oxidizers. The optimal temperature of psychrophilic ANME-2 mediating AOM at Hydrate Ridge ranges between $4^{\circ} \mathrm{C}$ and $16^{\circ} \mathrm{C}$ (Nauhaus et al. 2002). The AOM organisms of Eckernförde show a mesophilic temperature optimum between $16^{\circ} \mathrm{C}$ and $28^{\circ} \mathrm{C}$. This is most likely a consequence of the seasonal temperature changes in Eckernförde Bay in contrast with Hydrate Ridge, where the AOM organisms experience a constant temperature of $4^{\circ} \mathrm{C}$ (Suess et al. 1999). The occurrence of ANME2 organisms in temperate coastal habitats, observed here for the first time, has been proposed by Orphan et al. (2001a) based on the occurrence of ANME-2-related phylotypes in highly reduced, methane-rich salt-marsh sediments (Munson et al. 1997).

Sedimentary biomarkers related to ANME-2 were found only in trace amounts (M. Elvert, pers. comm.). At Sta. B, within the section 25-30 and 30-35 cm, 20 and $80 \mathrm{ng}$ g dry $\mathrm{wt}^{-1} s n$-2-hydroxyarchaeol were detected, respectively. These concentrations are 10-50 times lower compared with gas hydrate-bearing sediments at Hydrate Ridge (M. Elvert, pers. comm.). This agrees with the abundance of aggregates: ANME-2 cells at Hydrate Ridge are about three orders of magnitude more abundant than at Eckernförde Bay (Boetius et al. 2000; Treude et al. 2003). More detailed investigations are needed of the ANME-2 distribution within the AOM zone of Eckernförde Bay sediments, as their abundance in the present study was determined only for a few sections of the investigated sediment that revealed highest AOM activity. Nevertheless, the data indicate a correlation between aggregate abundance and methane availability. Higher abundances are found at sites with higher methane fluxes into the sulfate-methane transition. This is also shown by the poten- tial AOM revealing 10 times lower rates in Eckernförde Bay compared with Hydrate Ridge (Nauhaus et al. 2002; Treude et al. 2003).

Environmental control of AOM in Eckernförde Bay sediments - At both stations studied in Eckernförde Bay, significant seasonal changes occurred in AOM rates, which seems to be coupled to biogeochemical or physical parameters. In general, two major factors are known to control AOM activity: the availabilities of sulfate and methane. AOM is observed to be restricted to sulfate-containing sediments and its rate increases with methane concentration (Hoehler et al. 1994; Nauhaus et al. 2002). In the sediments of Eckernförde Bay, a close coupling between AOM and sulfate reduction was confirmed by a significant inhibition of AOM through molybdate addition. AOM is also known to be limited to the anoxic sediment due to a high sensitivity to oxygen among the group of methanotrophic archaea (Zehnder and Brock 1980). In the sediments of Eckernförde Bay, the inhibition of AOM by oxygen was confirmed by in vitro experiments under oxic conditions. Temperature, on the other hand, may regulate the rate of AOM depending on the temperature optimum of the organisms. Because the AOM organisms of Eckernförde Bay sediments revealed a mesophilic character in vitro, their turnover rates should be affected by in situ temperature changes. In the following, we will discuss these four major parameters and their impact on AOM activity and distribution in the sediments of Eckernförde Bay in more detail.

Oxygen: At both stations, AOM was reduced in the 0- to 1-cm interval in late September and March compared with early September. One reason may be the introduction of oxygen as a consequence of sediment resuspension during stormy weather. Because the activity and presence of aerobic methanotrophs within the top $0-5 \mathrm{~cm}$ was confirmed by potential rate measurements (this study) and by molecular identification of aerobic methanotrophs (Eppelin 2002), we cannot exclude that the activity in the $0-$ to $1-\mathrm{cm}$ interval represent aerobic methane oxidation. The low activity in the

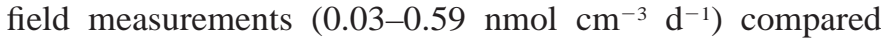
with potential measurements $\left(4.6-9.1 \mathrm{nmol} \mathrm{cm}^{-3} \mathrm{~d}^{-1}\right)$ could then be a result of fast oxygen depletion during the $48-\mathrm{h}$ incubation, leading to an underestimation of the turnover rate.

Sulfate: The penetration depth of sulfate in Eckernförde Bay sediments is mainly controlled by SR (Whiticar 1978; Bussmann et al. 1999; Whiticar 2002). In early and late September, SR at Sta. A and B was enhanced at the sediment surface due to freshly sedimented organic matter and/or higher temperature. The fresh input of organic matter is confirmed by a high Chl $a$ content at the sediment surface. Sulfate penetration was restricted to the upper $25 \mathrm{~cm}$. Unfortunately, AOM rates could not be determined deeper than $25 \mathrm{~cm}$. However, we can speculate that major AOM was restricted to the sulfate-penetrated sediment due to the close coupling between AOM and SR found in this study. It was shown in previous experiments that a net AOM, i.e., AOM that is not a part of the enzymatic reversal of methanogen- 
esis, is inhibited when sulfate is removed from the sediment (Zehnder and Brock 1979; Hoehler et al. 1994).

In March, sulfate penetrated deeper than $30 \mathrm{~cm}$, although bottom water salinity, and therefore also surface sulfate concentration, was lower compared with September. The deeper penetration of sulfate is explained by a drop of SR to about one third of the September activity in the top $10 \mathrm{~cm}$. This was most likely for two reasons: the organic matter was in an advanced degradation stage, as reflected by reduced $\mathrm{Chl}$ $a$ concentrations and higher chlorin indices compared with September, and the ambient temperature had dropped from $11^{\circ} \mathrm{C}$ to $4^{\circ} \mathrm{C}$. SR is reported to decrease threefold to fourfold during the cold season (temperature change of $10-15^{\circ} \mathrm{C}$ ), even when large amounts of organic matter are available in the sediment (Westrich and Berner 1988; Klump and Martens 1989). The higher sulfate penetration should have enabled major AOM activity to proceed into zones deeper than $25-\mathrm{cm}$ depth. The steady increase in AOM below $20 \mathrm{~cm}$ at both stations supports this hypothesis. However, the true penetration depth of AOM activity has to remain speculative because of lacking AOM data below $25 \mathrm{~cm}$.

The deeper penetration of sulfate, and thus the deeper presence of SR during cold ambient temperatures, might have shifted major methanogenesis to below $30 \mathrm{~cm}$. Sulfatereducing bacteria generally compete effectively with methanogens for hydrogen and acetate, which are substrates for the two major pathways of methanogenesis (Zehnder 1988). Such correlations of temperature with the depth distribution of SR and methanogenesis have been reported for seasonal variations at Cape Lookout Bight, North Carolina (Martens et al. 1986). However, because we detected considerable methanogenic in vitro activity in sulfate-free slurries from 5- to 40-cm sediment depth (March sampling), the potential of methanogenesis appears to be present also within sediments that feature sulfate-reduction activity in situ. Possibly the metabolism of the methanogenic archaea in the SR zone might be based on methylotrophic pathways utilizing noncompetitive substrates. It is also probable that the methanogens are inactive in situ as long as sulfate is present but are stimulated in our incubations due to the inhibition of sulfate reduction. A similar stimulation might also, to some extent, take place in situ, when the penetration depth of sulfate decreases during summer months. A third possibility would be a coexistence of methanogens and sulfate reducers in the sediment due to a temporal and spatial heterogeneity caused by bioturbation and gas ebullition that relieves competition and allows more diverse populations to thrive. The clear decrease in methane production rates toward the sediment surface would then indicate a decrease in the methanogenic population. However, because we did not test for a preference of methanogenic substrates or determined methanogenic biomass, the correlation between sulfate penetration and methanogenic activity remains speculative.

The higher methane production in March compared with September was unexpected. Due to the difference of in situ temperatures during sampling, we supposed a larger methanogenic population during the warm season. Because the treatment of the slurries was the same, we cannot attribute this difference to methodology.

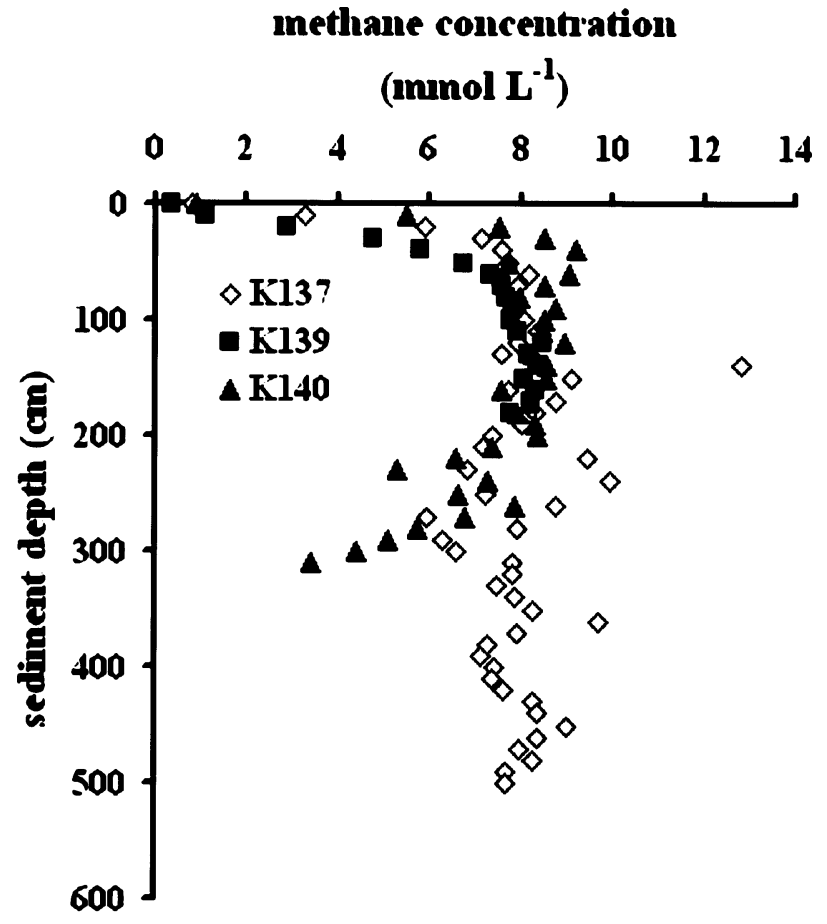

Fig. 8. Methane concentration profiles measured in the vicinity of Sta. A in an earlier study (Abegg and Anderson, 1997). Data were kindly provided by F. Abegg.

Temperature: In addition to the indirect impact of temperature on the vertical distribution of AOM by way of SR and the resulting sulfate penetration, temporal variations in AOM rate were also found to be directly correlated with temperature changes. In March, AOM at Sta. A and B was lower between 0 and $25 \mathrm{~cm}$ compared with early September, although methane concentrations at Sta. B were higher. This is most likely a consequence of low temperature, as potential $\mathrm{AOM}$ at $4^{\circ} \mathrm{C}$ was half that at $12^{\circ} \mathrm{C}$. The lower rates enabled more methane to diffuse upward.

Methane: In our study, AOM was never measured down to depths of saturated methane concentrations, which are around $7 \mathrm{mM}$ in Eckernförde Bay (Fig. 8; Abegg and Anderson 1997). We suggest, however, that major AOM did not occur below the depth of sulfate penetration for reasons mentioned before, and therefore major AOM activity might have been restricted to the top $25 \mathrm{~cm}$ of the sediment in early and late September. This is also confirmed by good agreement between integrated areal AOM rates (between 0.83 and $1.50 \mathrm{mmol} \mathrm{m}^{-2} \mathrm{~d}^{-2}$ ) and methane fluxes calculated from methane profiles of an earlier study (between 0.66 and $1.88 \mathrm{mmol} \mathrm{m}^{-2} \mathrm{~d}^{-2}$; Abegg and Anderson 1997; Fig. 8). We calculated the fluxes according to Treude et al. (2005) using a methane-diffusion coefficient of $\mathrm{D}_{\text {methane }}=8.7 \times 10^{-5} \mathrm{~cm}^{2}$ $\mathrm{s}^{-1}$, after Iversen and Jørgensen (1993), and a mean porosity of 0.88 .

We hypothesize that two transport mechanisms of methane impacted the vertical distribution of AOM in Eckernförde Bay sediments: molecular diffusion of methane from the methanogenic into the sulfate-reducing zone and advec- 


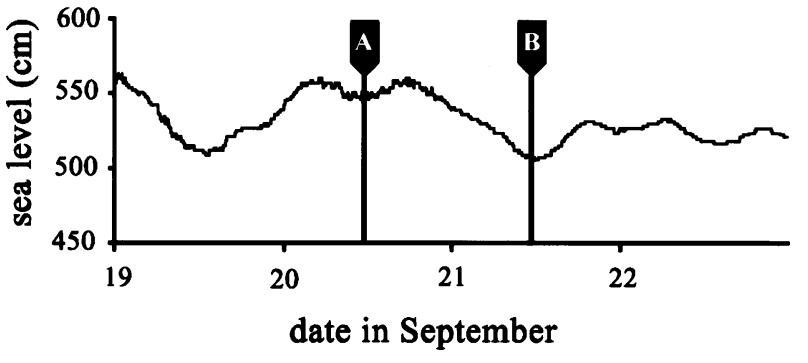

Fig. 9. Sea level in Eckernförde Bay between 19 and 22 September 2001. The sampling times at Sta. A and B, respectively, are marked. Sea level is given in centimeters above absolute altitude. Data were provided by the Wasser- und Schiffahrtsamt Lübeck, Germany.

tive transport of methane in the form of gas bubbles rising from the depth of gas-bubble formation to the sediment surface. We build this hypothesis on two observations: AOM was often highest within the deepest interval $(20-25 \mathrm{~cm})$, i.e., in the diffusive transition between methanogenic and sulfate-reducing sediment, and AOM was occasionally also enhanced above the diffusive transition, i.e., above $20 \mathrm{~cm}$ depth (see Sta. B, late September).

A distinct increase in AOM above the diffusive transition, as observed at Sta. B in late September, was not found at Sta. A, which was sampled $1 \mathrm{~d}$ earlier. We can exclude the impact of changes in temperature or sulfate penetration because both were similar at the two stations. Rather, we assume that a rise of gas bubbles, caused by a drop in hydrostatic pressure at Sta. B, might be responsible for the different AOM distributions. This assumption is based on a drop in sea level of about $40 \mathrm{~cm}$ between the sampling at Sta. A and B (Fig. 9). This explanation is supported by frequently observed increases in gas-bubble releases into the water column of Eckernförde Bay from water depths around $26 \mathrm{~m}$ during sea-level decreases of 20-40 cm (Jackson et al. 1998). Mattson and Likens (1990) similarly reported methane ebullition in a shallow lake $(11 \mathrm{~m})$ to be correlated with changes in local air pressure (18\% increase per millibar drop in air pressure). The decrease in hydrostatic pressure could result in an expansion of gas bubbles in the sediment. Such an expansion may cause instability and rise of the bubbles due to increased buoyancy. On their way to the surface, bubbles may partly dissolve into the pore water and lead to enhanced AOM rates. This explanation remains hypothetical, as we found no direct evidence of dissolved methane bubbles in the methane profile preserved at time zero. Because methane bubbles generally rise in distinct conduits (Abegg and Anderson 1997), the core subsampled for AOM/SR possibly experienced such a rise of bubbles, whereas the nearby replicate core subsampled for methane concentrations at time zero did not. Hence, the influence of rising gas bubbles needs to be investigated under well-monitored or controlled conditions in future investigations.

Our experiments with sediment slurries demonstrated that the organisms mediating AOM in Eckernförde Bay sediments have a large capacity for retaining methane from below. Potential rates of AOM at methane saturation were always 4-10 times higher compared with field measurements
Table 3. Comparison of potential and field AOM at Sta. B. Rates determined in field measurements were averaged for the respective depth interval. For potential determination of AOM, methane was saturated at atmospheric pressure (ca. $1.3 \mathrm{mmol} \mathrm{L}^{-1}$ ).

\begin{tabular}{cccccc}
\hline \hline & \multicolumn{5}{c}{ AOM $\left(\mathrm{nmol} \mathrm{cm}^{-3} \mathrm{~d}^{-1}\right)$} \\
\cline { 2 - 6 } $\begin{array}{c}\text { Sediment } \\
\text { depth } \\
\text { (cm) }\end{array}$ & $\begin{array}{c}\text { Potential } \\
\text { rate } \\
\text { early Sep }\end{array}$ & $\begin{array}{c}\text { Potential } \\
\text { rate } \\
\text { early Mar }\end{array}$ & $\begin{array}{c}\text { Field } \\
\text { rate } \\
\text { early Sep }\end{array}$ & $\begin{array}{c}\text { Field } \\
\text { rate } \\
\text { late Sep }\end{array}$ & $\begin{array}{c}\text { Field } \\
\text { rate } \\
\text { early Mar }\end{array}$ \\
\hline $0-5$ & 28 & 50 & 2 & 2 & 1 \\
$5-10$ & 84 & 21 & 3 & 6 & 1 \\
$10-15$ & 15 & 67 & 4 & 8 & 1 \\
$15-20$ & 49 & 24 & 3 & 8 & 2 \\
$20-25$ & 54 & 69 & 7 & 6 & 5 \\
Sum & 229 & 231 & 19 & 31 & 10 \\
\hline
\end{tabular}

at undersaturated conditions (Table 3). Even at a low temperature $\left(4^{\circ} \mathrm{C}\right.$, corresponding to the in situ temperature in March), potential rates are two- to threefold higher than field measurements (compare Figs. 2, 3, and 6). Thus, the organisms should be able to react to fast changes in methane supply. Such a fast response is most likely not dependent on growth of the microbial population because doubling times of methanotrophic cells were found to be very long (4.5 months at $16 \mathrm{mmol} \mathrm{L}^{-1}$ methane for ANME-2 organisms; K. Nauhaus, pers. comm.). Instead, methanotrophic cells readily change their consumption rate according to the methane partial pressure (see also Nauhaus et al. 2002).

Global comparison of AOM in marine sediments-The magnitude of AOM $\left(\mathrm{nmol} \mathrm{cm} \mathrm{cm}^{-3} \mathrm{~d}^{-1}\right)$ in Eckernförde Bay can be determined as medium compared with other methanebearing sediments or methane-seep locations (compare Hinrichs and Boetius [2002] and references therein). At sites bearing gas hydrates close to the sediment surface, methane turnover is up to 100 times higher (Treude et al. 2003; Joye et al. 2004), whereas the turnover in sediments from an anoxic basin in British Columbia (Saanich Inlet) was about 10 times lower (Devol 1983). The crucial factor determining the magnitude of AOM seems to be the methane flux: highest methane turnover rates were found at locations with highest methane fluxes (Hinrichs and Boetius 2002).

Cape Lookout Bight, North Carolina, is a coastal system rather comparable with Eckernförde Bay. Although sediment accumulation there is about 10 times higher, the system reveals several similar characteristics: (1) methane originates from recent methanogenesis, i.e., no seepage from fossil deposits (Martens and Klump 1980); (2) methane saturation is reached within the top $50 \mathrm{~cm}$ (Hoehler et al. 1994; Martens et al. 1998); (3) seasonality is strong for temperature, sulfate penetration, and methane ebullition (Martens et al. 1986; Crill and Martens 1987; Hoehler et al. 1994); (4) AOM is impacted by the depth distribution of sulfate (Hoehler et al. 1994); (5) AOM rates range between 10 and $20 \mathrm{nmol} \mathrm{cm}-3$ $\mathrm{d}^{-1}$ (Hoehler et al. 1994). It is not known which organisms mediate AOM at Cape Lookout Bight or how large their populations are. For future work, it would be important to compare the size of AOM populations, the potential capacity 
of AOM, and the methane supply in different sediment systems.

Summary - Due to their high abundance in sediment layers revealing enhanced AOM activity, specimens of the Methanosarcinales-related ANME-2 cluster known from other methane-bearing locations are suggested to mediate AOM in Eckernförde Bay. However, at Eckernförde Bay, the archaea might express a different strategy by forming bacteria-free aggregates. AOM in this habitat could possibly be mediated solely by archaea, harboring the enzymatic apparatus of both AOM and SR.

The methane-turnover rates in the gassy sediments of Eckernförde Bay are intermediate compared with other methanebearing marine locations. We suggest that the distribution and magnitude of AOM are controlled by several environmental factors: (1) oxygen and (2) sulfate penetration that determine the vertical distribution, (3) temperature controlling the rate of AOM, (4) methane supply by molecular diffusion or advection of gas bubbles creating either stable or fluctuating methane consumption rates. Most of these factors depend on seasonal changes, such as temperature, water stratification, primary production, and microbial degradation processes, leading to a shallow AOM zone during the warm, productive summer season and to a slightly deeper AOM zone during the cold winter season. The mesophilic physiology of the organisms involved in AOM is in accordance with the strong seasonal changes in temperature. Besides seasonal factors, a drop in sea level might cause short-term variations in AOM due to a concurrent release of gas bubbles. Rising gas bubbles possibly represent an additional methane supply beyond the diffusive border, enabling AOM in the upper $20 \mathrm{~cm}$ of the sediment. Assuming saturated methane concentration of around $7 \mathrm{mmol} \mathrm{L}^{-1}$ in the methanogenic zone, AOM in Eckernförde Bay effectively retains upward diffusing methane and prevents larger parts of it from reaching the sediment-water interface. The only major transport mechanisms across the microbial barrier might be rising gas bubbles.

\section{References}

AbegG, F., And A. L. Anderson. 1997. The acoustic turbid layer in muddy sediments of Eckernfoerde Bay, Western Baltic: Methane concentration, saturation and bubble characteristics. Mar. Geol. 137: 137-147.

Albert, D., C. S. Martens, And M. J Alperin. 1998. Biogeochemical processes controlling methane in gassy coastal sediments-part 2: Groundwater flow control of acoustic turbidity in Eckernförde Bay Sediments. Cont. Shelf Res. 18: 17711793.

Albert, D. B., AND C. S. Martens. 1995. Stable isotope tracing of methane production and consumption in the gassy sediments of Eckernförde Bay, Germany. Forschungsanstalt der Bundeswehr für Wasserschall und Geophysik (FWG), Kiel 22: 114120.

Amann, R. I., B. J. Binder, R. J. Olson, S. W. Chisholm, R. Devereux, AND D. A. Stahl. 1990. Combination of $16 \mathrm{~S}$ rRNA-targeted oligonucleotide probes with flow cytometry for analyzing mixed microbial populations. Appl. Environ. Microbiol. 56: 1919-1925.

Anderson, A. L., F. Abegg, J. A Hawkins, M. E. Duncan, And
A. P. LyONS. 1998. Bubble populations and acoustic interaction with the gassy floor of Eckernförde Bay. Cont. Shelf Res. 18: 1807-1838.

Barnett, P. R. O., J. Watson, and D. Connelly. 1984. A multiple corer for taking virtually undisturbed samples from shelf, bathyal and abyssal sediments. Oceanol. Acta 7: 399-408.

Bodungen, B. von. 1975. Der Jahresgang der Nährsalze und Primärproduktion des Planktons in der Kieler Bucht unter Berücksichtigung der Hydrographie. Ph.D. thesis, Universität Kiel.

Boetius, A., T. Ferdelman, And K. Lochte. 2000. Bacterial activity in sediments of the deep Arabian Sea in relation to vertical flux. Deep-Sea Res. II 47: 2835-2875.

—, AND OTHERS. 2000. A marine microbial consortium apparently mediating anaerobic oxidation of methane. Nature 407: 623-626.

Bussmann, I., P. R. Dando, S. J. Niven, and E. Suess. 1999. Groundwater seepage in the marine environment: Role for mass flux and bacterial activity. Mar. Ecol. Prog. Ser. 178: 169-177.

CORD-RUwISCH, R. 1985. A quick method for the determination of dissolved and precipitated sulfides in cultures of sulfate-reducing bacteria. J. Microbiol. Methods 4: 33-36.

Crill, P. M., AND C. M. Martens. 1987. Biogeochemical cycling in an organic-rich coastal marine basin. 6. Temporal and spatial variations in sulfate reduction rates. Geochim. Cosmochim. Acta 51: 1175-1186.

Devol, A. H. 1983. Methane oxidation rates in the anaerobic sediments of Saanich Inlet. Limnol. Oceanogr. 28: 738-742.

Dietrich, G., K. Kalle, W. Krauss, And G. Siedler. 1975. Allgemeine Meereskunde. Gebrüder Borntraeger Berlin.

EpPelin, A. 2002. Charakterisierung aerob methanoxidierender Mikroorganismen an marinen Standorten. Diploma thesis. University Bremen.

Fossing, H, AND B. B. JøRGENSEN. 1989. Measurements of bacterial sulphate reduction in sediments: Evaluation of a single-step chromium reduction method. Biogeochemistry 8: 205-222.

Hansen, L. B., K. Finster, H. Fossing, And N. Iversen. 1998. Anaerobic methane oxidation in sulphate depleted sediments: Effects of sulphate and molybdate addition. Aquat. Microb. Ecol. 14: 195-204.

HANSEN, H.-P. 1993. Saisonale und langzeitliche Veränderungen chemisch-hydrographischer Parameter in der Kieler Bucht. Berichte aus dem Institut für Meereskunde 240: 2-31.

- H. C. Giesenhagen, AND G. Behrends. 1999. Seasonal and long-term control of bottom-water oxygen deficiency in a stratified shallow-water coastal system. ICES J. Mar. Sci. 56: $65-71$.

HinRICHS, K.-U., AND A. BoEtiUs. 2002. The anaerobic oxidation of methane: New insights in microbial ecology and biogeochemistry, p. 457-477. In G. Wefer, D. Billett, D. Hebbeln, B. B. Jørgensen, M. Schlüter, T. C. E. van Weering [eds.], Ocean margin systems. Springer-Verlag.

- J. M. Hayes, S. P. Sylva, P. G. Brewer, and E. F. De LONG. 1999. Methane-consuming archaebacteria in marine sediments. Nature 398: 802-805.

Hoenler, T. M., M. J. Alperin, D. B. Albert, and C. S. MarTENS. 1994. Field and laboratory studies of methane oxidation in an anoxic marine sediments: Evidence for methanogen-sulphate reducer consortium. Global Biogeochem. Cycles 8: 451463.

IVERSEN, N., AND T. H. BlACKBURN. (1981). Seasonal rates of methane oxidation in anoxic marine sediments. Appl. Environ. Microbiol. 41(6): 1295-1300.

—, AND B. B. JøRGENSEN. (1993). Diffusion coefficients of 
sulfate and methane in marine sediments: Influence of porosity. Geochim. Cosmochim. Acta. 57: 571-578.

Jackson, D. R., K. L. Williams, T. F. Wever, C. T. Friedrichs, AND L. D. WRIGHT. 1998. Sonar evidence for methane ebullition in Eckernförde Bay. Cont. Shelf Res. 18: 1893-1915.

JøRGENSEN, B. B.1978. A comparison of methods for the quantification of bacterial sulphate reduction in coastal marine sediments: I. Measurements with radiotracer techniques. Geomicrobiol. J. 1: 11-27.

Joye, S. B., A. Boetius, B. N. Orcutt, J. P. Montoya, H. N. Schulz, M. J. ERICKSON, AND S. K. Logo. 2004. The anaerobic oxidation of methane and sulfate reduction in sediments from Gulf of Mexico cold seeps. Chem. Geol. 205: 219-238.

Karpen, V. 2002. Fluid discharge at different seep environments: Distribution, flow rate, and influence on particle resuspension. Ph.D. thesis, Christian-Albrechts-Universität zu Kiel.

Klump, J. V., And C. M. Martens. 1989. The seasonality of nutrient regeneration in an organic-rich coastal sediment: Kinetic modeling of changing pore-water nutrient and sulfate distributions. Limnol. Oceanogr. 34: 559-577.

Krüger, M., G. Eller, R. Conrad, AND P. Frenzel. 2002. Seasonal variations in $\mathrm{CH}_{4}$ oxidation and pathways of $\mathrm{CH}_{4}$ production in rice fields determined by stable carbon isotopes and specific inhibitors. Glob. Change Biol. 8: 265-280.

, P. FRENZEL, AND R. ConRAD. 2001. Microbial processes influencing methane emission from rice fields. Glob. Change Biol. 7: 49-61.

LENZ, J. 1996. Plankton, p. 136-150. In G. Rheinheimer [ed.], Meereskunde der Ostsee. Springer Verlag.

Madigan, M. T., J. M. Martino, and J. Parker. 2000. Brock biology of microorganisms 9/e. Prentice-Hall.

Manz, W., M. Eisenbrecher, T. R. NeU, And U. SzewzyK. 1998. Abundance and spatial organization of Gram-negative sulfatereducing bacteria in activated sludge investigated by in situ probing with specific 16S rRNA targeted oligonucleotides. FEMS Microb. Ecol. 25: 43-61.

Martens, C. S., D. B. Albert, And M. J. Alperin. 1998. Biogeochemical processes controlling methane in gassy coastal sediments-Part 1. A model coupling organic matter flux to gas production, oxidation and transport. Cont. Shelf Res. 18: 1741-1770.

- - - AND -1999 . Stable isotope tracing of anaerobic methane oxidation in the gassy sediments of Eckernförde Bay, German Baltic Sea. Am. J. Sci. 299: 589-610.

$\longrightarrow$, N. E. BlaIR, AND C. D. GREEN. 1986. Seasonal variations in the stable carbon isotopic signature of biogenic methane in a coastal sediment. Science 233: 1300-1303.

— AND V. K. KLUMP. 1980. Biogeochemical cycling in an organic-rich coastal marine basin-I. Methane sediment-water exchange processes. Geochim. Cosmochim. Acta 44: 471-490.

Mattson, M. D., AND G. E. Likens. 1990. Air pressure and methane fluxes. Nature 347: 718-719.

MeYer-ReIL, L.-A., AND G. GRAF. 1984. Seasonal development of bacterial communities in a coastal marine sediment as related to the input of organic material. Actes de Colloques, Brest, France. IFREMER, 3: 55-59.

Michaelis, W., AND OTHERS. 2002. Microbial reefs in the Black Sea fueled by anaerobic oxidation of methane. Science 297: 1013-1015.

Milkert, D., U. HentschKe, And F. Werner. 1995. Influence of storms on sediments in Eckernförde Bay. Forschungsanstalt der Bundeswehr für Wasserschall und Geophysik (FWG), Kiel 22: 149-158.

Munson, M. A., D. B. Nedwell, And T. M. Embley. 1997. Phylogenetic diversity of archaea in sediments samples from a coastal salt marsh. Appl. Environ. Microbiol. 63: 4729-4733.
Nauhaus, K., A. Boetius, M. KrüGer, And F. Widdel. 2002. In vitro demonstration of anaerobic oxidation of methane coupled to sulphate reduction in sediment from marine gas hydrate area. Environ. Microbiol. 4: 298-305.

NitTrouer, C. A., AND OTHERS. 1998. Oceanographic processes and the preservation of sedimentary structure in Eckernförde Bay, Baltic Sea. Cont. Shelf Res. 18: 1689-1714.

ORPHAN, V. J., AND OTHERS. 2001a. Comparative analysis of methane-oxidizing archaea and sulfate-reducing bacteria in anoxic marine sediments. Appl. Environ. Microbiol. 67: 1922-1934.

, C. H. House, K.-U. Hinrichs, K. D. McKeegan, And E. F. DE Long. 2001b. Methane-consuming archaea revealed by directly coupled isotopic and phylogenetic analysis. Science 293: $484-487$.

Schubert, C. J., J. Niggemann, G. Klockgether, and T. G. FerDELMAN. 2005. Chlorin index: A new parameter for organic matter freshness in sediments. Geochem. Geophys. Geosyst., 6, Q03005, doi:10.1029/2004GC000837.

Snaidr, J., R. Amann, I. Huber, W. Ludwig, and K. H. SchleiFER. 1997. Phylogenetic analysis and in situ identification of bacteria in activated sludge. Appl. Environ. Microbiol. 65: 3976-3981.

Sørensen, K. B., K. Finster, And N. B. Ramsing. 2001. Thermodynamic and kinetic requirements in anaerobic methane oxidizing consortia exclude hydrogen, acetate and methanol as possible electron shuttles. Microb. Ecol. 42: 1-10.

SuESS, E., AND OTHERS. 1999. Gas hydrate destabilization: Enhanced dewatering, benthic material turnover and large methane plumes at the Cascadia convergent margin. Earth Planet. Sci. Lett. 170: 1-15.

Treude, T., A. Boetius, K. Knittel, K. Wallmann, and B. B. JøRGENSEN. 2003. Anaerobic oxidation of methane above gas hydrates at Hydrate Ridge, NE Pacific Ocean. Mar. Ecol. Prog. Ser. 264: 1-14.

, J. Niggemann, J. Kallmeyer, P. Wintersteller, C. J. Schubert, A. Boetius, A., And B. B. Jørgensen. 2005. Anaerobic oxidation of methane and sulfate reduction along the Chilean continental margin. Geochim. Cosmichim. Acta. 69(11): 2767-2779.

Westrich, J. T., AND R. A. Berner. 1988. The effect of temperature on rates of sulfate reduction in marine sediments. Geomicrobiol. J. 6: 99-117.

Wever, T. F., F. AbegG, H. M. Fiedler, G. Fechner, and I. H. STENDER. 1998. Shallow gas in the muddy sediments of Eckernförde Bay, Germany. Cont. Shelf Res. 18: 1715-1739.

WhitiCAR, M. J. 1978. Relationships of interstitial gases and fluids during early diagenesis in some marine sediments. Sonderforschungsbereich 95: Wechselwirkung Meer-Meeresboden. Ph.D. thesis, Universität Kiel.

- 2002. Diagenetic relationships of methanogenesis, nutrients, acoustic turbidity, pockmarks and freshwater seepages in Eckernförde Bay. Mar. Geol. 182: 29-53.

WidDEL, F., AND F. BAK. 1992. Gram-negative mesophilic sulfatereducing bacteria, p. 3352-3378. In A. Balows, H. G. Trüper, M. Dworking, W. Harder and K.-H. Schleifer [eds.], The prokaryotes. Springer-Verlag.

ZEHNDER, A. J. B. 1988. Biology of anaerobic microorganisms. Wiley.

, AND T. D. BRoCK. 1979. Methane formation and methane oxidation by methanogenic bacteria. J. Bacteriol. 137: 420432.

, AND - 1980. Anaerobic methane oxidation: Occurrence and ecology. Appl. Environ. Microbiol. 39: 194-204.

Received: 7 February 2005 Accepted 5 June 2005 Amended: 6 July 2005 